\title{
MANUFACTURER'S NEGLIGENCE OF DESIGN OR DIRECTIONS FOR USE OF A PRODUCT
}

\author{
DIX W. NOEL'
}

THERE are a few jurisdictions where the rule of MacPherson $v$. Buick Motor Co. ${ }^{1}$ that a manufacturer may be liable for negligence to remote users of his product is only now being accepted, ${ }^{2}$ but in most parts of the country it is evident that the MacPherson principle has long since been adopted and has received extensive development. Most of this development has occurred in the situation where the plaintiff alleges simply that the particular chattel involved in the accident was negligently and defectively manufactured. In an increasing number of recent cases, however, the plaintiff has undertaken to establish that the defendant's product as a whole-as distinguished from a particular item carelessly made-is so designed as to create an unreasonable danger.

While there has been substantial authority for many years that a manufacturer's duty to use due care extends to the design and specifications of his product, $^{3}$ nevertheless in the design cases, particularly those involving widely-used products made by established manufacturers, judges and juries have been understandably hesitant to impose liability. This hesitation results partly from a reluctance to let a jury pass on a product prepared by experts in the field, and partly from the realization that a judgment for a particular plaintiff may open the door to many additional claims and suits. Occasionally there has been apprehension that a judgment for the plaintiff will necessitate extensive remodeling, or perhaps even removal from the market of some much-used and widely-advertised product, with serious consequences to both the manufacturer and his employees.

In spite of these important considerations, negligence of design, specifications, or composition has been established in a steadily increasing number of cases. This negligence takes many forms. For example, the manufacturer may

$\dagger$ Professor of Law, University of Tennessee.

1. 217 N.Y. 382,111 N.E. 1050 (1916).

2. So far there has been no explicit acceptance of the rule in Mississippi, but it apparently would have been applied, if negligence had been established, in E.I. du Pont de Nemours \& Co. v. Ladner, 221 Miss. 378, 73 So. 2d 249 (1954), and a federal court has decided that Mississippi would apply the doctrine. Mason v. American Emery Wheel Works, 241 F.2d 906 (1st Cir.), cert. denied, 355 U.S. 815 (1957) (applying Virginia law). Likewise, in Virginia a federal court has taken the position that the MacPherson rule in substance applies in that state. Pierce v. Ford Motor Co., 190 F.2d 910 (4th Cir.), cert. denied, 342 U.S. 887 (1951) (applying Virginia law). There still is some doubt about the complete acceptance of the doctrine in Maryland. See 1 Frumer \& Friednan, Products Liability $\$ 5.03$, at 23 (1960) [hereinafter cited as Frumer \& FrIfdMan].

3. See, e.g., Reusch v. Ford Motor Co., 196 Wash. 213, 82 P.2d 556 (1938) ; 2 RestateMENT, Torts $\$ \$ 395$, comment $c$; 398 (1934); 2 HARPER \& JAMES, ToRts $\$ \$ 28.3$ to -.4 (1956) [hereinafter cited as 2 HARPER \& JAMSES]. 
have failed to utilize some available safety device, such as an automatic cut-off on a vaporizer. In other cases the manufacturer has used some new material without sufficient testing, with the result, for example, that a new alloy used to support the wings of an airplane soon develops metal fatigue and the wing gives way in flight. Sometimes there is simply a failure to foresee hazards from a particular design, as when a part of the braking machinery of a bus is placed so close to the ground that it is sheared off upon striking an obstruction on the road, or a hook of insufficient strength is supplied to support a tree trimmer who must swing from one high branch to another.

In some of the cases the main issue has been whether a product designed in a certain way is accompanied by proper directions for use or by adequate warnings. An example of improper directions for use, as distinguished from a failure to warn, occurs when the user of a machine is directed to perform some operation at a point where a slight misstep will cause injuries. On the other hand, a design accompanied by an inadequate warning is exemplified by a situation where the user of a transplanting machine is adequately instructed to use a pipe to deflect exhaust fumes from a tractor, but is not warned of the danger, as well as the discomfort, when the tractor is used without the deflector. ${ }^{4}$

Where the hazard can be removed by warnings or directions for use, it is evident that the consequences of a judgment for the plaintiff are not especially serious for the manufacturer. As a result, there is less reluctance to allow recovery when the attack on the product is based on improper directions or warnings than when it is claimed that the basic design is hazardous. The duty to give adequate warnings as well as directions for use has been carefully analyzed in a frequently cited article. ${ }^{5}$ While that duty often cannot be separated from negligence of design, the emphasis in this study will be on cases where the principal difficulty has been that the basic design of the product is unsafe. $^{0}$

As indicated, the courts have not been concerned in cases involving negligence of design with defects in an individual product resulting from a miscarriage of the manufacturing process. In that situation the MacPherson decision itself, involving a particular automobile wheel with spokes made of defective wood, established liability for negligence. While problems remain

4. J.C. Lewis Motor Co. v. Williams, 85 Ga. App. 538, 69 S.E.2d 816 (1952) (retailer's liability). The cases involving the other situations suggested here will be discussed later in the text.

5. Dillard \& Hart, Product Liability: Directions for Use and the Duty to Warn, 41 VA. L. Rev. 145 (1955). The more recent decisions on the matter of warnings and directions are well analyzed in 1 FRUMrR \& FrIEDMAN $\$ \$ 8.01$ to -.06 .

6. Design negligence has received little attention. The only significant article on this aspect of the subject is limited to automobiles. Katz, Liability of Automobile Manufacturers for Unsafe Design of Passenger Cars, $69 \mathrm{HARV}$. L. REv. 863 (1956). Two recently published treatises on products liability give more attention to negligence of design, but relate most of the important cases to the duty to warn. See generally FrUMIER \& FRIEDMAN; HURSH, Amierican Law of Products Liabuity (1961). 
in that type of case, they are mainly problems of proof, often relating less to negligence than to the necessity of showing that the defect existed at the time the product left the manufacturer's plant and did not result from subsequent misuse or expectable wear of the product. On the other hand, in the cases where negligence of design or in directions for use is asserted, the matter of establishing causation has only occasionally presented serious difficulty. ${ }^{7}$ Here the main problem, as will be shown, has been to establish negligence.

As in the case of other applications of the MacPherson rule, it is not essential, with reference to design, that the product be incapable of doing harm. The manufacturer does not have to make a product which is "accident-proof" or "fool-proof." Liability is imposed only when an unreasonable danger is created. Whether or not this has occurred should be determined by general negligence principles, which involve "a balancing of the likelihood of harm, and the gravity of harm if it happens, against the burden of the precaution which would be effective to avoid the harm."' There has been a considerable tendency to lose sight of these basic negligence principles in the field of manufacturers' liability, and to insist that the chattel be "inherently" or "imminently" dangerous before liability is imposed. ${ }^{10}$ These terms seem to imply that the harm threatened must be more substantial, or more likely to occur, than would be the case under the usual unreasonable danger test. ${ }^{11}$ Many of the recent decisions, however, have applied general negligence principles to cases involving safety of design or specifications, and have found that all dangerous things are to be classed as "inherently dangerous." 12 Thus in a case involving use of a harmful wood preservative the court said:

The question of liability should be approached from the standpoint of the standard of care to be exercised by the reasonably prudent person in the shoes of the defendant manufacturer or supplier. Such an approach will eliminate any necessity of determining whether a particular product is "inherently dangerous." 13

7. See text accompanying notes $222-63$ infra.

8. Campo v. Scofield, 301 N.Y. 468,95 N.E.2d 802 (1950); Blissenbach v. Yanko, 90 Ohio App. 557, 562, 107 N.E.2d 409, 411 (1951).

9. 2 HARPER \& JAMIES $\$ 28.4$, at 1542 .

10. So in a case involving the use of inferior glass in a door, the court stated that there was no liability "unless the article is inherently dangerous." Watts v. Bacon \& Van Buskirk Glass Co., 18 IIl. 2d 226, 163 N.E.2d 425 (1959), discussed at text accompanying note 127 infra. See also Yaun v. Allis-Chalmers Mfg. Co., 253 Wis. 558, 34 N.W.2d 853 (1948) (hay baler with exposed rollers not inherently dangerous), discussed at text accompanying note 102 infra; Beznor v. Howell, 203 Wis. 1, 233 N.W. 758 (1930) (sparklers not inherently dangerous); Kerwin v. Chippewa Shoe Mfg. Co., 163 Wis. 428,157 N.W. 1101 (1916) (shoes with nailed soles made to look as if soles were sewn, not imminently or inherently dangerous).

11. See 2 Harper \& James $\$ 28.9$; Prosser, Torts $\$ \$ 4$ (2d ed. 1955).

12. Carter v. Yardley \& Co., 319 Mass. 92, 103, 64 N.E.2d 693, 700 (1946); Annot., 164 A.L.R. 559 (1946). See also 1 FruMer \& FrIEDMAN \$ 5.03[1].

13. Smith v. Atco Co., 6 Wis. 2d 371, 383, 94 N.W.2d 697, 704 (1959). 
Under this approach, negligence of design has been found in the case of a number of ordinary objects, such as a lounge chair, ${ }^{14}$ or a top with a tack not strong enough to hold a spring when the top is wound up..$^{15}$

With reference to the gravity of the harm if it occurs, it is established as a general doctrine of products liability that a manufacturer is not liable unless there is risk of "substantial bodily harm" and that this means something more than trivial injury. ${ }^{10}$ The MacPherson case, while extending liability to dangerous things generally, states that the product must be "reasonably certain to place life and limb in peril" if negligently made. ${ }^{17}$ This language has been retained, but its connotations have been somewhat softened. It has recently been applied in the design field to such things as a rubber exerciser which was held to involve only a risk of minor injuries, ${ }^{18}$ and a small tear gas gun made to resemble a fountain pen, where again the court thought that nothing more than temporary and minor harm was to be anticipated. ${ }^{19}$ In both of these decisions there were vigorous dissenting opinions, and it is doubtless to be expected that there will be considerable difference of opinion as to what bodily harm should be regarded as substantial.

While the harm threatened must be substantial, considerably more attention has been given by the courts to the question of whether the harm threatened, assuming it will be substantial, is likely to occur. After considering the various types of negligence of design or composition which have been alleged in the cases, analysis will be directed to the factors bearing on the central problem of likelihood of harm. Some of these factors are the effect of prior safe, or unsafe, use of the same design; the obviousness of the danger; and the effect of warnings or representations of safety. Problems of likelihood are complemented by problems of foreseeability, and the next section of the article will accordingly be devoted to the latter problems, emphasizing the care and skill demanded of the manufacturer as an expert in his field and special, recurring problems of foreseeability. Finally consideration will be given to such matters as termination of the risk created by the manufacturer and the effect of contributory fault.

14. Matthews v. Lawnlite Co., 88 So. 2 d 299 (Fla. 1956), discussed at text accompanying note 20 infra.

15. Gittelson v. Gotham Pressed Steel Corp., 266 App. Div. 866, 42 N.Y.S.2d 341 (1943).

16. 2 Restatentenx, Torts $\$ 395$, comment $c$ (1934); Poplar v. Bourjois, Inc., 272 App. Div. 74, 69 N.Y.S.2d 252 (1947), aff'd, 298 N.Y. 62, 80 N.E.2d 334 (1948) (applying Maryland law). Thus in a case involving a detergent alleged to be of dangerous composition, it was not enough to show that the product caused "mere redness of hands" to "a small percentage of persons," for this did not establish foreseeability of any substantial harm. Lehner v. Procter \& Gamble Mfg. Co., 208 Misc. 186, 143 N.Y.S.2d 172 (Sup. Ct. 1955).

17. 217 N.Y. $382,389,111$ N.E. 1050,1053 (1916).

18. Jamieson v. Woodward \& Lothrop, 247 F.2d 23 (D.C. Cir.), cert. denied, 355 U.S. 855 (1957).

19. Scurfield v. Federal Labs., Inc., 335 Pa. 145, 6 A.2d 559 (1939), discussed at text accompanying note 122 infra. 


\section{Types of Negligence of Design or Composition}

The best introduction to this expanding field of tort law may be an examination of the generic situations in which a manufacturer has been held liable for negligence of design or composition. Though counsel for plaintiffs have discovered a variety of artful variations in recent years, three basic situations seem evident. Sometimes a concealed danger has been created by the manufacturer's design; more often the manufacturer has failed to supply some needed safety device in designing his product; and in an increasing number of cases the complaint has been that the design called for materials of inadequate strength. These situations will be considered in turn.

\section{Concealed Dangers}

A case which clearly involved a concealed danger is Matthezes $v$. Lazenlite $\mathrm{Co}^{20}$ While the plaintiff was inspecting an aluminum lounge chair at a retail store he sat down in it, placing his hand on the arm, with his third finger extended over and under the arm rest. Thereupon some moving parts of the chair amputated his finger "with the ease that one clips a choice flower with pruning shears." In reversing an order dismissing the complaint, the court stated that "one is not required to guard against danger in places where it is not expected to be." The opinion goes on to say that if this mechanism was required, it should have been covered by a housing. ${ }^{21}$

A different sort of concealed danger was involved in Garbutt v. Schechter. ${ }^{22}$ There a rather heavy woman sat down in an S shaped chrome chair. Because its center of gravity was unusually far forward, the chair tipped and the woman fell to the floor. In holding that the jury could find an unreasonable risk, the court remarked that the chair was "of the type of newfangled creations that are called modern, and which are designed more to please the eye than to provide the stability one expects to find when reposing the anatomy upon a chair in a place of business." 23

There is a questionable decision involving what seems to be a concealed defect in a washing machine. ${ }^{24}$ An unexposed movable pin, used to keep the wringer in place, tended to become worn down rather soon, with the result that when a sheet was pulled through the wringer, the pin was likely to be pulled out of position and the wringer released. The plaintiff purchased one of the machines from the defendant, which marketed the product as its own. She used it for about two years, and then was injured when the pin was

20. 88 So. 2 d 299 (Fla. 1956).

21. Id. at 301 .

22. 167 Cal. App. 2d 396, 334 P.2d 225 (1959).

23. Id. at 399,334 P.2d at 227 . The suit in this case was against the owner of the premises rather than against the manufacturer, but it would seem that even a stronger case could have been made against the manufacturer, who ordinarily would be more aware than the retailer that an overweight person might cause the chair to overturn.

24. Auld v. Sears, Roebuck \& Co., 261 App. Div. 918, 25 N.Y.S.2d 491 (1941). 
loosened and the wringer swung around suddenly as she was pulling a sheet through it. A judgment for the plaintiff was set aside on the ground that there was no evidence of negligence of design and "no duty on a manufacturer to furnish a machine that will not wear out." It was remarked that the remedy against such conditions lay in periodic inspections. A concurring judge, however, agreed with the reversal only because of erroneous instructions about liability for breach of warranty, and thought that there should be a new trial on the negligence issue, stating:

The life of the unexposed pin was two years, while that of the wringer was ten years. This was known to defendant, which marketed the wringer as manufacturer. The jury may have found that a reasonably circumspect housewife would not know or be concerned about such unexposed part, which in this case became defective in two and a half years, or maybe less. There was presented for the jury a fair question as to whether the defendant should not have given notice on the sale of the wringer that an interior part might need replacement within two years, and that otherwise there would be danger in continued use of the wringer after that time. ${ }^{25}$

In view of the concealed nature of the pin and its tendency to require replacement well before any other parts in the machine, this view seems sound. In the absence of a warning attached to the machine, the design involved an unreasonable danger.

A leading aircraft decision, $\mathrm{DeV}$ ito $v$. United Air Lines, ${ }^{26}$ involving a fair weather crash against a hillside, seems based to some extent on a concealed defect of design. The manufacturer of the aircraft, a Douglas DC-6, had notice from test pilots that carbon dioxide, an agent used to combat fire, tended to enter the cockpit of the plane in such quantities as to affect the pilot adversely. The manufacturer had further notice of the serious nature of this danger from a report on the matter by some aero-medical specialists. There was evidence that the crash, which occurred immediately after a period of erratic flying, was caused by the escape into the cockpit of carbon dioxide in such toxic proportions as to cause the pilots to lose consciousness. The decision against the manufacturer was based largely on its failure to warn the airline of the need for the crew to wear oxygen masks upon release of the gas into any fuselage compartment. Reference also was made, however, to the fact that the Civil Aeronautics Regulations provided for design arrangements to prevent hazardous quantities of carbon dioxide from entering habitable compartments. While it was considerably easier in this case to establish breach of a duty to warn than to establish that the design was defective, it seems likely that negligence of design was in fact present. This type of plane had been grounded for lack of adequate fire protection, and the information about the risk from

25. Id. at 919, 25 N.Y.S.2d at 493-94 (concurring opinion).

26. 98 F. Supp. 88 (E.D.N.Y. 1951). Cf. Maynard v. Stinson Aircraft Corp., 1 Av. L. REp. 698 (Mich. Cir. Ct. 1937) (fuel escaped to fuselage near exhaust because carburetor drainpipe was too short; negligent design found) ; but cf. Peusch v. Ford Motor Co., 196 Wash. 213, 82 P.2d 556 (1938). 
entrance into the cockpit of undue amounts of carbon dioxide was deliberately withheld from the Civil Aeronautics Administration, perhaps because of apprehension of further grounding on account of this concealed defect of design.

A recent case, McKinney $v$. Frodsham, ${ }^{27}$ illustrates a concealed danger of design in the automotive field. As a Volkswagen car rounded a curve, the door flew open and a small girl fell out. The plaintiff's expert, a professor of automotive engineering, tested the car and some sixteen other Volkswagen cars of the same 1955 model, and testified that on approximately twenty-five per cent of the cars tested, including the one involved in the accident, the doors, although apparently closed, could be forced open without manipulation of the handles upon application of from ten to twenty-five pounds of force to the latch area. He stated that the door mechanism was particularly apt to stick in the apparently latched condition when it was covered with sticky resin from oxidized grease. Other witnesses testified that Volkswagen doors were hard to close. Under these circumstances the court held that the design of the lock mechanism could be found to be unreasonably dangerous, and that the defendant dealer could have discovered the danger by exercise of due care. If the dealer could be found negligent, it seems clear that there was negligence on the part of the manufacturer as well. It might be added, however, that since the plaintiff's Volkswagen and the others tested were at least two years old at the time of testing, and since only a small number of cars were tested, the testimony as to negligence of design in this case does not seem very convincing. ${ }^{28}$

\section{Failure to Provide Safety Features or Devices}

A considerable number of cases in recent years have involved failure to provide some available safety device in designing a product. Occasionally even though the safety device is in customary use in the industry a manufacturer may escape liability on the ground that its absence is apparent. ${ }^{29}$ In a number

27. 356 P.2d 100 (Wash. 1960).

28. A somewhat similar concealed defect was involved in a case where a defectively designed latch on the hood of a Ford car tended to become unfastened when the car passed over rough ground, with the result that the hood would fly up and obscure the vision of the driver. Ford Motor Co. v. Wagoner, 183 Tenn. 392, 192 S.W.2d 840 (1946), discussed at text accompanying notes $236-42$ infra. The defendant escaped liability in that case because a safety catch had been provided to the purchaser of the car to correct the defect.

In some of the cases involving concealed defects the danger is not from the product itself, but from the way it is packaged. See, e.g., Central Steel Tube v. Herzog, 203 F.2d 544 (8th Cir. 1953) (applying Iowa law) (plaintiff struck by lever on grain swather when coil spring released in unpacking machine); Katz v. Swift \& Co., 276 F.2d 905 (2d Cir. 1960) (applying New York law) (plaintiff struck in eye by rubber band used in improper manner to bind shanks of butchered lamb). Compare Crandall v. Stop \& Shop, 288 Ill. App. 543, 6 N.E.2d 685 (1937) (spring clamp designed to keep lid on glass jar of fruit not inherently dangerous as obvious that precautions necessary in removing clamp).

29. See, e.g., Messina v. Clark Equip. Co., 263 F.2d 291 (2d Cir. 1959) (applying New York law), discussed at text accompanying note 89 infra; Yaun v. Allis-Chalmers Mffg. Co., 253 Wis. 558, 34 N.W.2d 853 (1948), discussed at text accompanying note 102 infra. 
of decisions, however, the latent defect rule has not precluded a holding that the failure to provide an available safety device is sufficient to establish negligence.

The decision most clearly based on this ground is Lindroth v. Walgreen $\mathrm{Co}^{30}$ There an infant was severely burned when a fire started near his crib, and it was found that the fire was caused by a vaporizer which became overheated when the water in it boiled away after about forty-five minutes. One of the more specific counts was that the defendant manufacturer negligently failed to provide a cutout device which would automatically cut off the current before the vaporizer reached the temperature at which it was likely to set fire to surrounding objects. It appeared that some makers of vaporizers had cutouts which operated successfully, while others did not have this device. A judgment against both defendants for $\$ 65,000$ was affirmed. While the opinion is devoted almost exclusively to the adequacy of the evidence as to how the fire started, it indicates that the absence of the automatic cutoff was sufficient to make the vaporizer "an inherently dangerous instrument." On the other hand, where the only objection made to the design of a vaporizer was that it had a loose lid, with the result that when it was upset a child was scalded, a verdict for the plaintiff was set aside. ${ }^{31}$ It appeared that the vaporizer in question was of "standard and conventional type and design" and that the loose lid provided a "natural safety valve." No available safety device" to prevent this type of accident was pointed out by the plaintiff.

A significant recent case, Blitzstein v. Ford Motor Co., ${ }^{32}$ effectively illustrates how a plaintiff may sometimes save himself from a directed verdict by realizing that some needed safety feature was omitted. This case involved an Anglia car, manufactured in England by the English Ford Company, and sold in that country to the American Company, which in turn sold it to the Alabama distributor from whom it was purchased by the plaintiff. A few days after he had bought the car, the plaintiff turned on the ignition and the vehicle exploded and burned, causing personal injuries. There was evidence that the gas tank, which was located in the trunk of the car, had a small leak in its upper part; that there were no holes or other outlets for gasoline or its vapor to escape from the trunk; and that when the plaintiff switched on the ignition, a spark thereby generated and caused the explosion and fire. Suit was brought against both the English and the American companies, on negligence and warranty grounds. It was found in the trial court that the American Company was not liable for a breach of express or implied warranty because of lack of privity, and that there was no jurisdiction over the English company. As the court of appeals remarked, referring to these developments, the plaintiff, though wounded, "fought on bravely until the trial court administered the coup de grâce-a directed verdict in favor of American Ford." Since the

30. 338 Ill. App. 106, 87 N.E.2d 22 (1949), aff'd, 407 Ill. 121, 94 N.E.2d 847 (1950).

31. Blissenbach v. Yanko, 90 Ohio App. 557, 107 N.E.2d 409 (1951).

32. 288 F.2d 738 (5th Cir. 1961) (applying Alabama law). 
American Company received the Anglia car completely assembled, the court of appeals agreed that the inspection it was bound to make as a mere distributor would not have revealed the small crack in the gas tank, assuming that the defect existed at the time of the plaintiff's purchase. The court went on to hold, however, that the case should have been submitted to the jury on the ground that there may have been negligence of design in failing to have holes or vents in the trunk. It remarked that the American Ford Company from its long experience in the design and manufacture of automobiles should have realized the inherent danger. The opinion speaks of a duty to warn, and perhaps the distributor would have been protected by an adequate warning of the unsafe design; but it would seem that the manufacturer of the car would be under a duty definitely to provide the vents, if they were found by the jury to be needed for safe construction. It is fantastic to suppose that even with a warning users of the car would check the trunk for fumes before opening it with a lighted cigarette in hand or before turning on the ignition.

Other cases in which the finding of unreasonable danger seems to turn mainly on the absence of an available safety device involve the lack of a reducing valve on a large coffee urn, ${ }^{33}$ the absence of a device to guard against excessive pressure in a boiler used to heat a house, ${ }^{34}$ and the failure to have an adequately designed "boom dog" to keep the boom on a crane from falling when in a raised position. ${ }^{35} \mathrm{~A}$ recent case indicates that failure to equip a gas heater with an automatic control device which will shut off all gas in the event of a failure of the pilot light flame may cause the heater to be unreasonably dangerous. ${ }^{36}$ In Basin Oil Co. v. Baasch-Ross Tool Co., ${ }^{37}$ a suspension plug designed for use with oil well equipment lacked a "safety factor adequate to withstand the live-load impacts" with the result that in three cases heavy equipment dropped 10,000 feet into the wells, causing difficulties sufficient to require abandonment of the oil remaining in the zone-a result for which the supplier of equipment was held liable. A quite recent aircraft case which involved a crash of a Boeing B- 52 bomber, ${ }^{38}$ holds that an alternator drive could be found to be improperly designed where it had insufficient overspeed protection for the turbine wheel on the drive, and insufficient guard-

33. Muller v. A.B. Kirschbaum Co., 298 Pa. 560, 148 At1. 851 (1930), discussed at text accompanying note 79 infra.

34. Crane v. Davies, 30 Ala. App. 471, 8 So. $2 d 189$ (1941), rev'd, 242 Ala. 570, 8 So. 2d 196 (1942), because of lack of substantial evidence that the boiler was manufactured or assembled by defendant.

35. Brooks v. Allis-Chalmers Mfg. Co., 163 Cal. App. 2d 410, 329 P.2d 575 (1958).

36. Shepard v. Rheem Mfg. Co., 112 S.E.2d 380 (N.C. 1960). Compare an earlier gas burner case in which the fact that an available safety device was not utilized helped support a verdict for the plaintiff. Hartmon v. National Heater Co., 240 Minn. 264, 60 N.W. 2d 804 (1953).

37. 125 Cal. App. 2d 578, 271 P.2d 122 (1954).

38. Boeing Airplane Co. v. Brown, 291 F.2d 310 (9th Cir. 1961) (applying Washington law). Evidence of subsequent changes in design was admitted in this case for the limited purpose of showing the practicability of suggested safeguards. 
ing of the wheel. As a result the wheel developed excessive speed, disintegrated, and penetrated a fuel tank, causing a fire and the explosion of the bomber. Another recent decision, of an unusual sort, involves a failure to prevent excessive noise from a telephone receiver. ${ }^{39}$ While the plaintiff was talking over the phone, an explosive sound caused permanent injury to her ear. The noise also apparently cracked the ear piece of the receiver, which was about thirty years old. Experts testified that modern phones are equipped with various safety devices to limit the sound from the receiver. Under the circumstances the court sustained a finding of negligence on the part of the supplier of a receiver without the customary safeguards. ${ }^{40}$

Occasionally a manufacturer puts out a product with a safety device but continues to market an older model without this device. Thus in Pontifex $v$. Sears, Roebuck \& Co., ${ }^{41}$ the latest model power mower marketed by the defendant had the rope which was pulled to start the machine permanently attached to a spring recoil mechanism. The plaintiff was injured when she was struck in the eye by the rope on an earlier model. The only negligence alleged was that the rope was not attached to the mechanism as on the later models. In holding that a verdict properly was directed for the defendant, the court said that it did not think "that it could be held to be negligence to sell an old model machine, not equipped with a safety device of later models." Likewise in Kientz v. Carlton-another power mower case-where a verdict was directed for the defendant supplier, the court stated, "No law of which we are aware requires that a merchant sell only the latest models or those having specified safety features." ${ }^{\text {22 }}$ It would seem, however, that the basic inquiry should be as to whether or not the earlier model is unreasonably dangerous, and the presence of the safety device on later models, if the device removes a serious risk and is easily attached, might well have a bearing on that issue. In many cases, however, the courts probably would conclude, as in the Pontifex and

39. Gandy v. Southwestern Bell Tel. Co., 341 S.W.2d 554 (Tex. Civ. App. 1960); Note, 15 ARK. L. REv. 212 (1961).

40. In another recent case the difficulty arose from lack of a locking device on a motorcycle part. Saeter v. Harley Davidson Motor Co., 8 Cal. Rptr. 747 (Sup. Ct. 1960). See also Tracy v. Finn Equip. Co., 290 F.2d 498 (6th Cir. 1961), cert. denied, 368 U.S. 826 (1961) (applying Tennessee law). It appears from the complaint in the Tracy case that the negligence of design on which recovery was based consisted in the failure to have on a mulching machine "a safety device or interlock on the clean out door ... which would automatically stop the machine's operation when the clean out door is opened and while the operator or crew member is exposed to the blades of the blower fan." The plaintiff there lost a forearm when the blower fan started up while he was attempting to clear the fan blades. His recovery in the trial court still is being considered on a general appeal, following the unsuccessful special appeal on due process grounds.

41. 226 F.2d 909 (4th Cir. 1955) (applying Virginia law).

42. 245 N.C. 236 , 96 S.E.2d 14 (1957). In the latest power mower case, however, involving a rotary design not fully guarded at the rear, the court allowed the case to go to the jury as to issues of negligence of design and contributory negligence. The jury found for the defendant manufacturer. Siemer v. Midwest Mower Corp., 286 F.2d 381 (8th Cir. 1961) (applying Missouri law). 
Kientz decisions, that where the only evidence of unreasonable danger submitted by the plaintiff is the use of a safer design in later models, this evidence is not substantial enough to prevent a directed verdict. ${ }^{43}$ Perhaps to give substantial weight routinely to the use of safety devices on later models would place too much of a penalty on improvements, especially in view of the tendency of juries to find that "the machine did it."

This matter may be carried a step further when it is asserted that there is a duty to install some new safety device even after a product has been sold. So in Ellis v. H. S. Finke, Inc., ${ }^{44}$ one of the defendants had manufactured a material hoist for use in construction work. The contractor for whom the plaintiff was working purchased one of the hoists. Subsequently the manufacturer developed a new safety device, and sent three of the new devices to the defendant distributor, requesting him to install them on three machines already sold, including the one sold to the plaintiff's employer. The distributor installed two of the devices, but failed to install one on the hoist sold to the employer of the plaintiff. Thereafter the plaintiff was injured when the hoist suddenly fell forty feet to the ground.

It was asserted that the manufacturer was negligent in the construction of the original hoist, in failing to notify the purchaser of the hazardous condition of the machine, and in failing to follow up its instructions to the dealer to install the new safety device on all three hoists already sold. The trial judge directed a verdict for both defendants, because of lack of evidence of any "negligence or defective construction of the original machine." $\mathrm{He}$ also stated, however, "But if it had been shown here that safety device would have prevented the fall of this elevator, why I would have submitted that case to you, and I believe you would have found for the plaintiff." This suggests that the principal basis for the decision was lack of cause in fact, rather than absence of negligence, and that both defendants may have been under a duty to use due care to install the new safety device on the machines already sold. In affirming, the appellate court simply agreed that there was no causal connection between the falling of the hoist and the absence of the safety device, without expressing any opinion as to the merits of the plaintiff's case had the causal connection been present. It would seem that where a safety device can be easily attached and will remedy a real danger, there should be a duty to take reasonable steps to supply the safety device even to those to whom the product already has been sold. There is no doubt that such a duty exists when it develops that the original design is clearly defective. ${ }^{45}$

It should be added that even though a machine is equipped with a safety device, the manufacturer may incur liability if under some conditions the de-

43. See also Marker v. Universal Oil Prods. Co., 250 F.2d 603, 605 (10th Cir. 1957) (applying Oklahoma law to hold no duty to incorporate only features representing ultimate in safety).

44. 278 F.2d 54 (6th Cir. 1960) (applying Tennessee law).

45. See, e.g., Ford Motor Co. v. Wagoner, 183 Tenn. 392, 192 S.W.2d 890 (1946) (hood of certain model of car needs safety catch to assure that it will not fly up in face of 
vice will not be operative. This point arose in a recent case where the plaintiff's fingers were cut off by the descent of a knife in a paper cutting machine. ${ }^{46}$ It appeared that when a door normally opened only for inspection purposes suddenly opened, the braking mechanism would not work properly. In holding that the complaint was improperly dismissed, the court said the jury could "find that defendant's design of the guillotine-type paper-cutting machine in such a manner as to permit the access doors to interfere with the safety mechanism, without at least warning the operator of the hazard foreseeable by it, was negligence." 47

\section{Defective Composition}

Occasionally the difficulty with a design is that it specifies materials of inadequate strength for the purpose the product is intended to serve. ${ }^{48} \mathrm{~A}$ case in which particular emphasis was placed on lack of adequate strength is Goullon v. Ford Motor Co., ${ }^{49}$ involving the steering wheel on a tractor. While the plaintiff was driving the tractor backward, turning in his seat, the rim of the steering wheel broke in his hand, with the result that he fell and was run over by the machine. It appeared that the seat of the tractor was without side support, and that the operator normally relied on the wheel for support. The rim of the wheel was constructed entirely of rubber and fiber, while all other tractor manufacturers used metal or wood for the rim. Tests made of the rim after the accident showed that it would break under a strain less severe than the one it might receive from the effort of a heavy man to save himself from

driver); Comstock v. General Motors Corp., 358 Mich. 163, 99 N.W.2d 627 (1959) (vital part in new type of brake found to be inadequate). These cases are discussed at text accompanying notes $236-48$ infra.

The decision in the Ellis case itself may be strengthened by the fact that a plate on the hoist bore the warning "no riders allowed," indicating that the hoist should be used only for materials. The opinion, however, does not discuss this point. The matter of unintended uses is discussed at notes 164-95 infra and accompanying text.

46. Beckhausen v. E.P. Lawson Co., 9 N.Y.S.2d 726, 174 N.E.2d 327 (1961). A subsequent verdict for $\$ 125,000$ was set aside as excessive. 221 N.Y.S.2d 753 (1961).

47. Id. at 727, 174 N.E.2d at 328. Likewise in Hartmon v. National Heater Co., 240 Minn. 264, 60 N.W.2d 804 (1953), the fact that other safety devices on a gas burner all were nullified when a certain plug was removed was a factor in upholding a verdict for the plaintiff.

48. In addition to the cases discussed in this section consider the following cases examined elsewhere in the text: Northwest Airlines, Inc. v. Glen L. Martin Co., 224 F.2d 120 (6th Cir. 1955) (applying Ohio law) (alloy which develops metal fatigue used to support wings of airplane), discussed at text accompanying note 158 infra; Watts v. Bacon \& Van Buskirk Glass Co., 20 Ill. App. 2d 164, 155 N.E.2d 333 (1958) (glass asserted to be of insufficient strength used for door), discussed at text accompanying note 127 infra; O'Donnell v. Asplundh Tree Expert Co., 13 N.J. 319, 99 A.2d 577 (1953) (malleable rather than forged iron used in hook supplied to support man engaged in pruning tree), discussed at text accompanying note 160 infra; Auld v. Sears, Roebuck \& Co., 261 App. Div. 918, 25 N.Y.S.2d 491 (1941) (pin which wears out ahead of rest of product used in washing machine), discussed at text accompanying notes 24-25 supra.

49. 44 F.2d 310 (6th Cir. 1930) (applying Kentucky law). 
falling, and an expert fixed the tensile strength of the rim at only slightly over half the amount necessary for safety. The trial court directed a verdict for the defendant, but the appellate court held a jury properly could find that the steering wheel might break "under the strain of use which the manufacturer should reasonably expect," and that if this was the case, the design involved unreasonable danger. The case was distinguished from an earlier one where it appeared that the seat on a tractor gave way. Examination of that case indicates that all strains reasonably to have been expected had been anticipated in the design of the seat, and that it had been adequately tested. ${ }^{.00}$

Materials of insufficient strength likewise were involved in a case where a stepladder suddenly collapsed while the plaintiff was standing on the top step. ${ }^{51}$ The collapse occurred when the spreader, or locking device, gave way. The American Standard Safety Code for Portable Wood Ladders prescribed a metal spreader. The defendant manufacturer had used a wood spreader, and the wood selected, ponderosa pine, was particularly weak. Under these circumstances it is not surprising that the court upheld a verdict for the plaintiff. Likewise, where a three-eighths inch metal cable was employed to support the stairway portion of a fire escape, the jury was permitted to find, on the basis of expert testimony, that the cable was of insufficient size and strength to withstand the stresses involved. ${ }^{52}$ So also where a trailer was attached to its tractor by means of a "fifth wheel" made by the defendant, materials of insufficient strength were involved. ${ }^{53}$ The "fifth wheel" was held in position by means of four one-half inch bolts, which sheared when the plaintiff applied the brakes, with the result that the tractor broke loose. Experts testified that the bolts used were not of sufficient strength and should be larger unless, as was customary, supplementary U-bolts were clamped around the fifth wheel to hold it in place. This testimony was enough to support a finding of negligence of design where the customary U-bolts were not added. In a quite different sort of accident it was an inadequate tack used to hold a wound spring on a top which caused the difficulty. .54 When a child wound the top, the tack flew out and struck him in the eye. It was held that a jury could properly find that "the tack was inadequate for the purpose for which it was used."

50. Davlin v. Henry Ford \& Son, 20 F.2d 317 (6th Cir. 1927) (applying Michigan law).

51. Heise v. J.R. Clark Co., 245 Minn. 179, 71 N.W.2d 818 (1955).

52. Cornett v. Ficks Reed Co., 172 N.E.2d 183 (Ohio C.P. 1961).

53. Wallace v. Herman Body Co., 163 S.W.2d 923 (Mo. 1942); cf. Babylon v. Scruton, 215 Md. 299, 138 A.2d 375 (1958) (concrete slabs reinforced with overlapping short rods instead of longer rods; negligent design found).

54. Gittelson v. Gotham Pressed Steel Corp., 266 App. Div. 866, 42 N.Y.S.2d 341 (1943). But cf. Simmons v. Gibbs Mfg. Co., 170 F. Supp. 818 (N.D. Ohio 1959), aff'd per curiam, 275 F.2d 291 (6th Cir. 1960) (applying Ohio law).

55. In one of the older cases it appeared that only some four-penny nails, driven upward, had been used to support the deck of a tractor. When the operator walked on the deck, as was intended, he fell through into the machinery. In permitting the jury to find 
A related situation arises where the materials are of adequate strength except for the fact that a poorly designed part sets up unusual disintegrating stresses. In Fredericks $v$. American Export Lines, Inc., ${ }^{56}$ an iron support for a platform used by stevedores was made with a part that had a concave surface formed over too small a radius. This defect in design tended to increase greatly the stress put on the metal, so that it might fail even under a small load. A finding of negligence was upheld because of the inherent weakness resulting from this "stress raiser." This decision may have a significant bearing on claims against airplane manufacturers where it is alleged that a particular design set up stresses likely to cause the sudden tearing away of a wing when the plane is in highspeed flight.

Occasionally it is not the product itself but its container that is of inadequate strength. In one such case, Steele $v$. Rapp, ${ }^{57}$ the defendant supplied a beauty parlor with fingernail polish contained in a one-gallon glass bottle. While an employee of the beauty parlor was pouring some of the polish into a smaller bottle for use at her manicure desk, she dropped the large bottle. It broke and the polish "ignited and exploded," injuring another employee. Since the defendant knew or should have known that the polish was highly inflammable or explosive, it was asserted that there was negligence in distributing the product in a heavy glass bottle which would be handled by the employees of a beauty shop, as well as in failing to warn of its dangerous qualities. The opinion is devoted principally to a discussion of whether the intervening negligence of the employee who dropped the bottle did not save the defendant from liability, ${ }^{58}$ but in holding that the defendant's demurrer should have been overruled the court remarked that "had the defendant delivered the product in a safe container the explosion would never have occurred." $"$ Perhaps a warning would have been sufficient to change the result in this case, although it seems foreseeable that even employees fully advised of the inflammable and explosive character of the liquid might drop the fragile glass bottle and cause injury.

that a tractor so designed was "imminently dangerous" the court observed that "all that stood between the plaintiff and the most serious injury was . . . this nail ... driven into the wood from underneath." Pierce v. C.H. Bidwell Thresher Co., 153 Mich. 323, 328, 116 N.W. 1104,1106 (1908).

The most recent case on this point involved a surgical nail which became bent after insertion in the narrow cavity of the plaintiff's broken femur. A verdict for the plaintiff for $\$ 45,000$ was based to some extent on testimony that the nail was of inadequate strength, although it was also supported by evidence that the nail was defectively constructed with a crack that was likely to grow wider. Bowles v. Zimmer Mfg. Co., 277 F.2d 868 (7th Cir. 1960) (applying Indiana law). There was expert testimony that even if perfect, the nail would sustain a maximum force of 107 pounds. See Spies, Surgical Materials That Fail: A Medicolegal Study in Liability, 14 ARK. L. Rev. 1, 4 (1959).

56. 227 F.2d 450 (2d Cir. 1955), cert. denied, 350 U.S. 989 (1956) (applying New York law).

57. 183 Kan. 371, 327 P.2d 1053 (1958).

58. See text accompanying notes $189-92$ infra.

59. 183 Kan. at 386,327 P.2d at 1065 . 


\section{LIKELIHOOD OF HARM}

Whether the alleged negligence of design involves concealed dangers, lack of safety devices, or use of defective materials, the courts have placed special emphasis on the problem of whether the harm threatened is likely to occur. A number of relevant questions arise. Has the design been used safely in the past? Or has the manufacturer found the design unsafe in the past? How obvious is the danger created by the design? Is it a concealed danger? Has the manufacturer given instructions to use the product in a dangerous way or has he made unwarranted claims of the safety of the product? On the other hand, has the manufacturer rendered the design safe by giving adequate warning of its potential danger? These questions will be considered in turn.

\section{Extensive Safe Use by Defendant of the Same Design}

When a manufacturer has used a particular design for a long time or on an extensive scale without mishap, this would seem an important indication that no unreasonable risk is created by continued distribution of a product of a particular design. ${ }^{60}$ As one court puts it, "the longer a machine has been in use before it fails the more unlikely it is that the failure was due to defective construction or design."61 Besides tending to show that the design is not in fact unsafe, such evidence of harmless use tends to prove that even if a considerable risk of injury in fact was involved, the manufacturer was not unreasonable in failing to appreciate the hazard. ${ }^{62}$ Thus where an infant was alleged to have been poisoned by a metallic nipple manufactured by the defendant," the court emphasized that "many thousands of these appliances have been sold both in England and in the United States for a period of more than ninety years," without any significant complaint as to their safety or efficiency by the medical profession. Likewise in a case involving automobile brakes alleged to be of unsafe design, a principal basis for directing a verdict for the defendant was that if the alleged improper design were present, it would have been "apparent in some of the hundreds of thousands of such cars in general use at the time of this accident."

60. See 2 Harper \& JaAies $\$ 28.12$.

61. Darling v. Caterpillar Tractor Co., 171 Cal. App. 2d 713, 722, 341 P.2d 23, 29 (1959), discussed at text accompanying note 141 infra. So in a case where a tractor upended, the court emphasized in its holding for defendant that 300,000 such tractors had been used for years without similar accidents. Ford Motor Co. v. Wolber, 32 F.2d 18 (7th Cir.), cert. denied, 290 U.S. 565 (1929) (applying Illinois law). In Day v. Barber-Colman Co., 10 I1l. App. 2d 494, 135 N.E.2d 231 (1956), discussed at note 133 infra, the court emphasized that some 150 doors of the design alleged to be defective had been installed without any prior accidents.

62. See Morris, Proof of Safety History in Negligence Cases, 61 HARv. L. REv. 205, 233 (1948).

63. Cleary v. John M. Maris Co., 173 Misc. 954, 955, 19 N.Y.S.2d 38, 41 (Sup. Ct. 1940). See also Kientz v. Carlton, 245 N.C. 236, 96 S.E.2d 14 (1957), involving a power mower, where the plaintiff's failure to point out any other accidents with any similarly designed machine was one basis for directing a verdict against him.

64. Dillingham v. Chevrolet Motor Co., 17 F. Supp. 615, 617 (W.D. Okla. 1936). 
Actually the problem is not whether extensive safe use establishes lack of any unreasonable danger, but rather whether a jury's inference of danger in the face of evidence of such use is permissible. It is well settled ${ }^{65}$ that the following of a general custom in an industry does not always establish due care, but in the situation now under consideration the manufacturer is ready to show not only his conformity with the customary industry practice, but also that there has been extensive use of the particular product without any resulting mishap. Does such a showing conclusively negative the presence of an unreasonable danger?

This point was a vital one in Carpini v. Pittsburgh \& Weirton Bus Co. ${ }^{66}$ There a bus, full of passengers, was going down a long hill when the braking power failed and the vehicle crashed into a retaining wall near the foot of the hill. Eleven passengers were killed and forty-nine were injured. In a suit against the bus company, General Motors was joined as a defendant on grounds of negligence in the design of the braking system. This system involved the use of pet cocks to drain air chambers to get rid of moisture and other impurities. It was desirable to have the pet cocks as low as possible for sufficient drainage. In a loaded bus, they were close enough to the ground to be damaged by a stone or other object on the highway. After the accident a witness found a broken portion of a pet cock at the side of the highway amongst the debris swept off the road. This piece matched the remaining portion still on the bus. There was further testimony that the pet cocks could be guarded with a shield, and this testimony was strengthened by an admission of a coach chassis engineer of General Motors that a guarded pet cock was practical and would increase safety. There also was evidence that in truck operations pet cocks, located as these were, had been broken off by objects on the road. A principal defense was that experience over the years with this type of design showed that despite the millions of miles which vehicles of this sort had traveled on highways, no bus accident of this kind had been reported. The court held, however, that such testimony "was not conclusive any more than evidence of general practice in an industry is conclusive on whether operations are conducted with due care." The case thus holds that an unreasonable danger may be found by a jury in spite of extensive safe use, at least where a design which would have prevented the accident is shown to be quite feasible.

A more recent decision to the same effect, Hyatt v. Hyster Co., ${ }^{67}$ involved a crane mounted on a four-wheel frame which tapered toward the rear. There

65. See text accompanying notes 135-39 infra.

66. 216 F.2d 404 (3d Cir. 1954) (applying Pennsylvania law).

67. 106 F. Supp. 676 (S.D.N.Y. 1952), rev'd per curiam on stipulation of the parties, 205 F.2d 421 (2d Cir. 1953). In a somewhat similar case involving a fork lift truck which overturned when the boom was detached, the case was allowed to go to the jury even though there was testimony that no other trucks of this kind had overturned, but there the jury found for the defendant manufacturer. Persons v. Gerlinger Carrier Co., 227 F.2d 337 (9th Cir. 1955) (applying Oregon law). 
was a counter-weight at the rear to balance the weights lifted by the boom in front. While the crane was being towed along a cobblestone street it started to fall. The plaintiff jumped off before the machine turned over, but not soon enough to avoid the loss of a leg and an arm. In a suit against the manufacturer based on negligence of design, there was testimony that the center of gravity of the machine was too high, and that the "attachment and location of the counter-weight could have been effected so as to afford greater stability without sacrificing maneuverability." On the other hand there was testimony from the sales manager of the defendant that some four thousand similar machines, and 445 cranes completely identical with the one involved had been produced by the defendant and that there has been no previous complaints as to lack of stability. It further appeared that the crane involved in this accident had been in continuous use for about five years. It was held in spite of this unrebutted testimony as to extensive safe use of the same design that the case should be submitted to the jury. Even though the defendant showed motion pictures of the machine going over wedge shaped blocks four inches high, the jury returned a verdict for the plaintiff, in the sum of $\$ 165,000$. The finding of negligence seems sustainable since the crane did in fact turn over and there was no evidence that it struck an unpredictable sort of obstacle.

Long safe use also failed to establish safety of design in Beadles v. Servel, Inc. ${ }^{68}$ a somewhat unusual case involving a gas refrigerator. It appeared that the gas burner was so designed as to permit the deposit of uncombusted carbon particles which restricted the air supply. Unless the mechanism was regularly cleaned, the gas which burned would not be completely consumed, and dangerous carbon monoxide gas was formed. The plaintiffs, who purchased the machine second-hand with their house, were injured by the gas. The defendant contended that the use of the product "over a long period of time indicates as a matter of law that it is of proper design and construction." In rejecting this argument the court stated:

The nature of the alleged defect in this particular refrigerator was not that the machine wore out gradually. It was that with each moment of use the refrigerator became increasingly dangerous, as the carbon particles restricted the air supply to the burning flame and increased the generation of carbon monoxide gas, by reason of defective construction of the machine. In this light the period of satisfactory service before the defect caused harm does not indicate the machine was not defective as a matter of law, but merely that the defect was more insidious than sudden in its capability to cause harm. ${ }^{69}$

This case is perhaps a bit unusual in that the product became more dangerous with the lapse of time, but it nevertheless serves to indicate that when there is specific evidence of negligence of design, the defendant may not be protected from liability by long safe use. ${ }^{70}$

68. 344 I1l. App. 133, 100 N.E.2d 405 (1951).

69. Id. at 146,100 N.E.2d at 412 .

70. See also Martin v. Bengue, Inc., 25 N.J. 359, 371, 136 A.2d 626, 632 (1957), discussed at text accompanying note 208 infra ("The fact that the product may have been used 
It is evident from these decisions that even extensive safe use of the same design may not establish conclusively that there was no unreasonable danger, particularly where, as in the Hyatt and Carpini cases, there is testimony that the risk was readily discoverable and easily corrected. The thought seems to be that the absence of any prior accidents in this situation may have been due simply to good fortune, rather than to the absence of any unreasonable risk. It is believed that these decisions are sound in letting the matter go to the jury, at least where there is some expert testimony as to unsafe design. Where, however, there is no such testimony, it would seem that the evidence of extensive safe use should be regarded as sufficient to prevent an inference of negligence of design from the mere fact of the accident. This point is illustrated by the case of Solomon v. White Motor Co., ${ }^{71}$ where the flywheel on a tractor came apart, causing the machine to wreck, with resulting injuries to the plaintiff. It was alleged that the flywheel was improperly designed and that defective steel or steel alloy was used in its manufacture. The tractor was about five years old at the time of the accident, and had been operated between 100,000 and 200,000 miles without any prior trouble with the flywheel. There was no testimony as to just how the design or specifications of the flywheel were defective. Under these circumstances the court directed a verdict for the defendant, stating that where a chattel has been used for a long period of time, such as the five-year period here involved, there is a conclusive denial that the product "involved an unreasonable risk of bodily harm."72 Even where there is substantial evidence that the design may be unsafe, some of the older cases take the position that a considerable period of extensive safe use conclusively establishes that a design is not inherently dangerous, ${ }^{73}$ but this seems unsound under the modern unreasonable danger test. ${ }^{74}$

by many people over a considerable period of time without prior injury would not preclude the finding of foreseeability and negligence.") ; Farley v. Edward E. Tower \& Co., 271 Mass. 230, 171 N.E. 639, Annot., 86 A.L.R. 941 (1930), discussed at text accompanying note 210 infra (long safe use held not to preclude a finding of negligence).

71. 153 F. Supp. 917 (W.D. Pa. 1957). See Note, 56 Mrch. L. Rev. 651 (1958).

72. In an earlier case, Schindley v. Allen-Sherman-Hoff Co., 157 F.2d 102 (6th Cir. 1946) (applying Ohio law), it was alleged that a heavy ash gate had been improperly designed, in that certain lugs intended to stop the movement of the gate were not strong enough to withstand pressures to which they would be subjected. The court, in affirming a judgment for the defendant, was considerably influenced by the fact that gates of this same design had been extensively used, stating that defendant "had installed more than 2,000 of these Type ' $C$ ' gates throughout the country and had never had a complaint that they were defective in design or irregular in operation." Here, however, as in the Solomon case, there was a lack of any convincing expert testimony that the design of the gate was inadequate.

73. See, e.g., Gorman v. Murphy Diesel Co., 42 Del. 149, 29 A.2d 145 (1942) (explosion of diesel engine after sixteen months safe use) ; Ford Motor Co. v. Wolber, 32 F.2d 18 (7th Cir.), ccrt. denied, 280 U.S. 565 (1929) (applying Illinois law) (tractor somersaulted after two years use).

74. It might be added that in cases involving defectiveness of a particular item, evidence of long safe use of the particular item claimed to be defective is sometimes regarded as conclusively establishing that the product simply wore out and was not in fact defective 


\section{Unsafe Use by Defendant of Same Design}

It would seem that evidence of unsafe use of the same design, like evidence of safe use, should be admissible as to the issue of whether a particular design involves unreasonable danger. ${ }^{75}$ There are a few cases in which this view has been adopted. So in a case involving a drum of sulphuric acid evidence that a similar drum had burst elsewhere on the same day was admitted "for the purpose of showing the propensity of these drums to burst, and hence their dangerousness, and also as bearing on the cause of the burst of the Union drum." "'6 Likewise, in the Carpini case, ${ }^{77}$ the court admitted evidence that unguarded pet cocks on trucks, positioned as were those on the bus whose brakes failed, occasionally had been broken off by objects in the road. Furthermore, where a product harmful to allergic consumers is involved, it is now well settled that testimony as to other injuries caused by the product is admissible to show that an unreasonable danger is present. ${ }^{78}$

More frequently the evidence of unsafe prior use has been admitted not for the purpose of showing that the defendant was originally negligent in producing an article of given design, but simply to show that by the time of the accident in question the manufacturer had notice that the design involved an unreasonable risk, and should have taken some remedial action. This point was involved in Muller v. A.B. Kirschbaum $\mathrm{Co}^{79}{ }^{79}$ where a large coffee urn

when supplied. See, e.g., Auld v. Sears, Roebuck \& Co., 261 App. Div. 918, 25 N.Y.S.2d 491 (1941), aff'd without opinion, 288 N.Y. 515, 41 N.E.2d 927 (1942) ; Beckhusen v. E.P. Lawson Co., 9 App. Div. 2d 536, 196 N.Y.S.2d 531 (1960).

These decisions are not closely in point, however, with reference to negligence of design cases, for they are concerned with the matter of causation and whether in fact the defect in the particular product existed at the time it left the plant of the manufacturer. In the design cases, the issue is rather whether or not long safe use of the product is conclusive evidence that there was no foreseeable risk of harm from the design involved.

Even in the cases involving individual defects, recent decisions tend to allow the jury to find that there was originally a defective weld or the like even after many years of safe use of the item, particularly where the part in question is not one of those subject to wear while the machine is in operation. See, e.g., Pryor v. Lee C. Moore Corp., 262 F.2d 673 (10th Cir. 1958) (applying Oklahoma law) (fifteen years of safe use did not conclusively establish that a derrick weld was originally sound). This case overruled in Lynch v. International Harvester Co., 60 F.2d 223 (10th Cir. 1932) (applying Ollahoma law), where five years safe use of a threshing machine was regarded as "a conclusive denial" that the machine was "imminently dangerous to life and limb when defendant sold it." Id. at 224, 225.

75. See 2 Harper \& James $\$ 28.13 ; 1$ Frumer \& Friednan $\$ \$ 12.01$ [2], 12.01[3]. The other accidents would seem to bear on unreasonable danger of design even though they occur subsequently to the accident in question, although subsequent accidents of course would not be relevant with respect to notice. See Morris, supra note 62, at 205 .

76. Gall v. Union Ice Co., 108 Cal. App. 2d 303, 317, 239 P.2d 48, 58-59 (1951).

77. See text accompanying note 66 supra.

78. Wright v. Carter Prods. Inc., 244 F.2d 53 (2d Cir. 1957) (applying New York law) ; Noel, The Duty to Warn Allergic Users of Products, 12 Vand. L. Rev. 331, 334 (1959).

79. 298 Pa. 560, 148 Atl. 851 (1930). 
exploded, injuring the operator of the cafeteria in which it had been placed. In addition to introducing expert testimony that a reducing valve was essential to safe operation of the urn, the plaintiff showed that on three earlier occasions like accidents had occurred from failures to provide reducing valves and that the manufacturer was aware of these earlier accidents. The court held that this evidence was properly admitted, stating that "knowledge of the likelihood of injury is imparted by information of like occurrences under similar circumstances, and is a fact to be considered by the jury in determining whether proper precautions were taken." 80

More specific consideration was given to the particular purpose for which evidence of prior unsafe use can be introduced in Prashker $v$. Beech Aircraft Corp. ${ }^{81}$ a case involving allegations that the Beechcraft Bonanza plane had aerodynamic design defects. The plaintiff introduced testimony concerning specific defects of design, but the court found this testimony insufficient to take the case to the jury, concluding that the "alleged defects were either non-existent or present to an unavoidable extent." The chief interest of the case lies in the plaintiff's efforts to introduce evidence of earlier fatal accidents involving structural failure in flight by planes of similar design. Testimony was offered that there had been forty-five such accidents, and government statistics were offered to show "that over a six-year period prior to the accident in question the Bonanza had a rate of structural failure in flight approximately fifteen times the rate of all other single engine civil aircraft."

Testimony as to all but seven of the forty-five prior accidents was held to have been properly excluded on the ground that the other accidents involved earlier models lacking some improvements in the current model involved in the suit which "improved the structural strength of the airplane." As to the seven accidents involving planes of a design substantially the same as that of the current model, it was held that the trial court was correct in admitting evidence of these accidents only for the restricted purpose of showing notice of possible defects, and not to show the existence of a defect in design. In other words, it was held that the plaintiff must introduce some specific testimony that a defect in design existed, and only then could he introduce evidence of the other accidents, to show that the defendant realized or should have realized the presence of this defect, so that a duty to correct the defect or give additional warnings would arise.

The reasoning used to support this conclusion was that in each of the seven accidents in question there was considerable indication that the planes may have come apart because of the failure of the pilot to keep the plane under control. It appeared that the plane was subject to some lateral oscillation in rough air flight and this tended to produce vertigo and loss of control by a pilot who was unable to retain a point of reference either by means of vision

80. Id. at 566, 148 Atl. at 853-54. See also De Eugenio v. Allis-Chalmers Mfg. Co., 210 F.2d 409 (3d Cir. 1954) (applying New Jersey law).

81. 258 F.2d 602 (3d Cir.), Annot., 76 A.L.R.2d 91 (1961), cert. denied, 358 U.S. 910 (1958) (applying Delaware law). 
or instruments. In that connection, the manufacturer's literature had emphasized both the importance of retaining control, and the danger of losing control when instrument flight conditions were encountered by a pilot not skilled in instrument flying. Under these circumstances the court concluded:

The seven reports in evidence-and they may be assumed best to present the plaintiffs' case-invariably involve pilots unqualified to fly under instrument conditions who nonetheless were in such conditions or, in a few instances involving the unadmitted reports, pilots qualified for instrument flight who were in turbulent weather when the accidents occurred. To hold the aircraft responsible on such evidence would be utterly to disregard the factor of human fallability known inevitably to occur in such circumstances and would be patently unjustified. The reports, therefore, do not tend to prove the existence of a defect in design of the Bonanza. The cases cited by plaintiffs on the admissibility of prior occurrences as evidencing existence of a dangerous condition are consequently inapposite. ${ }^{82}$

For the same reasons the court considered that the statistics as to a high rate of structural failure of the Bonanza plane were not relevant to establish defectiveness or causation, since they tended to prove nothing more than did the individual accident reports. The opinion further indicated that the statistical report was not relevant even as to notice, in view of "what amounts to an explanation of each accident which contributed to the ultimate statistic."

While the Beech Aircraft case seems close to the line, it is distinguishable from cases in which evidence of prior unsafe use of the same design has been admitted to establish a dangerous design. In cases like the ones involving the bus with the pet cock dangerously near the ground and the coffee urn without the usual reducing valve, the accident may well have occurred without any improper handling of the product. In the Beech Aircraft case, however, there was a substantial likelihood of pilot failure in the case of a small airplane operating under instrument conditions with a pilot unskilled in instrument flying. If the seven other planes had come apart when visibility was good, or while being flown under instrument conditions by pilots skilled in that type of flying, the court probably would have admitted the evidence of the earlier accidents as tending to show an unsafe design. It then would hardly have been appropriate to say, as the court did, that evidence "that the planes came apart is not enough because of the compromise required with structural strength in designing an aircraft which will get off the ground." If the structural accidents had occurred at a time when the pilots probably were in control of the planes, the "compromise" made would seem to be one that was definitely unsatisfactory.

\section{Obviousness of Danger}

A final factor bearing on the likelihood of harm is the obviousness of the danger. It is frequently asserted that a design is not unreasonably dangerous

82. Id. at 608-09. 
because the risk is one which anyone immediately would recognize and avoid. For example, it is clear that there is no duty to provide a protective covering or a warning with a sharp knife or axe, and it is evident that the sharpness of such an instrument is not a defect. The risk of being cut is so obvious that no negligence of design or directions could be found even if the plaintiff were not barred by contributory negligence or voluntary assumption of risk. So it is said that the supplier's liability is restricted to cases where he has "no reason to believe that those for whose use the chattel is supplied will realize its dangerous condition." $\$$ Questions of obviousness of danger may arise in various forms. The problem may be one of applying the latent defect rule, of determining the effect of the manufacturer's instructions or representations of safety, or of weighing the sufficiency of a warning to make the design safe.

Latent Defects. Suppose the danger is somewhat less obvious than that from a sharp knife or axe? Many courts, influenced perhaps by the reluctance of juries to find contributory negligence or voluntary assumption of risk, still have been inclined to hold as a matter of law that there is no negligence unless the defective design can be classified as "latent." The leading decision relied on to support this view is Campo $v$. Scofield, ${ }^{84}$ a case involving an "onion-topping" machine which consisted of four steel rollers set in a rectangular frame. To start or stop the machine, it was necessary to shift a gear located about fifteen feet away on a tractor used for power. The plaintiff was injured while dumping a crate of onions over the machine, when his hands became caught in the rollers. It was asserted that the manufacturer was negligent in failing to provide a guard to prevent the hands of the user from coming into contact with the rollers, and in failing to provide an appliance by which the machine might be stopped quickly before serious injury occurred. In directing a verdict for the defendant, the court emphasized the requirement that the defect must be latent, stating,

Entirely lacking is the slightest suggestion that the machine possessed a latent defect or a danger unknown to plaintiff; entirely lacking is any recital that the absence of guards or a stopping device was unknown to him; and entirely lacking is any allegation of fact indicating that defendants foresaw or should reasonably have foreseen a danger to one using the machine for its intended purpose. ${ }^{85}$

Looking at the above quotation as a whole, it is submitted that the Campo decision indicates simply that obviousness of the defect, or even of the danger itself, should be one significant factor in the determination of whether or not the manufacturer has created an unreasonable risk. The language about foreseeability suggests that this remains the basic test, and that there should be no rigid requirement that the defect must be latent. Suppose, for example, in

83. 2 Restatenent, ToRts $\S 388$, comment $b$ (1934). As one court puts it, "We have not reached the state where the manufacturer is under a duty of making a machine accident proof or fool proof." Campo v. Scofield, 301 N.Y. 468, 472, 95 N.E.2d 802, 804 (1950).

84. 301 N.Y. 468,95 N.E.2d 802 (1950).

85. Id. at 472,95 N.E.2d at 804. 
the Campo case, there had been testimony that after numerous accidents all manufacturers of onion-topping machines, except the defendant, regularly provided their machines with a guard and stopping device. Could it then be said as a matter of law, that the defendant did not create an unreasonable risk, even though the defect was not "latent" in the sense that the absence of the guard and of the stopping device was evident? Any definite requirement that the defect or the danger must be latent seems to revert to the concept that a chattel must be "inherently" dangerous, and this concept has been replaced under the modern decisions, by the rule that the creation of any unreasonable danger is enough to establish negligence. Under the modern rule, even though the absence of a particular safety precaution is obvious, there ordinarily would be a question for the jury as to whether or not a failure to install the device creates an unreasonable risk. ${ }^{86}$

The concept that the danger itself, as distinguished from the defect, must be latent, bears more precisely on the basic issue of unreasonable risk, but courts emphasizing the "latent" requirement are apt to find that the danger is obvious whenever the alleged defect of design is obvious. This point is illustrated in a later New York case, Inman v. Binghampton Housing Author$i t y,{ }^{87}$ where a child fell off the porch of an apartment house. The principal negligence alleged was that the porch was unfenced, and the step down from it did not extend the full length of the stoop. It was held, reversing the appellate division, that the complaint failed to state a cause of action in the absence of an allegation that the structure possessed "a latent defect or an unknown danger." 88

The controversial character of a rigid "latent" requirement is well displayed in a recent federal decision, Messina v. Clark Equipment Co. ${ }^{89}$ The machine there involved was an earth mover with a large bucket which was raised and lowered by two scissors arms, pivoted to the machine behind the operator's compartment or cab, with one arm of the scissors on each side of the cab. The operator had raised the scissors and the attached bucket. He then stepped out of the cab. As he did so the scissors and bucket suddenly fell, and he was crushed between an arm of the scissors and the cab. In a suit against the manufacturer, there was testimony that "it was customary among manufacturers of similar machines to provide guards and safety devices to prevent an operator from getting into or out of the cab while the arms were raised." 10 The court sustained a dismissal of the plaintiff's case, on the ground that since the operator knew that the cab did not have the customary safety device, there was no "latent defect" or "danger unknown to the decedent."

Judge Clark, in a vigorous dissenting opinion, took the view that in the Campo case the New York court in substance had made the basic issue the

86. 2 HARPER \& JAMES $\$ 28.5$.

87. 3 N.Y.S.2d 137,143 N.E.2d 895 (1957).

88. Id. at 145,143 N.E.2d at 899.

89. 263 F.2d 291 (2d Cir. 1959) (applying New York law).

90. Id. at 292 . 
lack of any reasonable foreseeability of harm, with the result that the point that the defect was not latent, though important in that case, was not the basic test of liability. He thought that a different situation was presented, where, as in the Messina case, the evidence showed "a general industry practice of installing safety devices to avoid precisely the accident which caused the death of plaintiff's decedent." On the basis of this evidence Judge Clark considered that there was greater foreseeability of injury than in the Campo case, and that a jury could properly "hold a manufacturer to such standards as have been overwhelmingly and voluntarily adopted by his industry."91 He thus took the view that the Campo and Inman decisions "did not shift the basic inquiry as to the reasonable unforeseeability of the danger to a sterile definitional quibble over whether the injury was caused by a 'latent' or a 'patent' defect." With reference to a concession by plaintiff's counsel that the lack of the safety device was obvious, Judge Clark pointed out that this did not amount to a concession that the danger was obvious. It would seem that the danger in this case in fact was not obvious or why would other manufacturers have found it advisable to install the safety device designed to keep the operator from stepping out of the cab? Perhaps there was contributory negligence or voluntary assumption of risk, but this does not necessarily follow, for the manufacturer, after widespread experience with the machines in various areas, might be much more cognizant of the danger than an individual operator.

As indicated above, however, the latent defect concept still has considerable influence in the field of negligence of design, and this influence is not confined to New York. The concept played an important role in a Wisconsin case involving a hay bailer with unguarded rollers ${ }^{92}$ and in a Kansas case involving a tractor with an exposed universal joint in which the operator's clothing became caught. ${ }^{93}$ A recent North Carolina case, Tyson v. Long Mfg. Co., ${ }^{94}$ involved a tobacco harvester. A perforated sprocket was only partially guarded, with the result that a worker's thumb was crushed when the machine lurched and threw her against it. In finding no evidence of negligence, the court emphasized the point that the alleged defect in design was plainly visible and not "latent." The court cited, besides the Campo decision, an earlier North Carolina case involving an inexpensive power mower without available safety devices, ${ }^{95}$ pointing out that the absence of the safety features "was obvious, not latent."

91. Id. at 294.

92. Yaun v. Allis-Chalmers Mfg. Co., 253 Wis. 558, 34 N.W.2d 853 (1948), discussed at text accompanying note 102 infra.

93. Stevens v. Allis-Chalmers Mfg. Co., 151 Kan. 638, 100 P.2d 723 (1940), discussed at note 187 infra.

94. 249 N.C. 557,107 S.E.2d 170 (1959).

95. Kientz v. Carlton, 245 N.C. 236, 96 S.E.2d 14 (1957), discussed at text accompanying note 42 stipra. The obvious defect rule was referred to in the latest power mower case, involving a rotary design unguarded at the rear, as supporting a finding of contributory negligence, but, significantly, the court did allow the case to go to the jury on the issue of negligence of design. Siemer v. Midwest Motor Co., 286 F.2d 381 (8th Cir. 1961) (applying Missouri law). 
Perhaps the most significant recent case, however, in which the turning point of the decision was the obviousness of the danger, is Jamieson v. Woodward \& Lothrop..$^{96}$ The product there involved was an exerciser known as a "Lithe-Line." This was simply a rubber rope, about the thickness of a pencil, about forty inches long, with loops on the ends. The product was enthusiastically described by the manufacturer as "easily the best turn done to the body beautiful since the curve was invented." With the exerciser the plaintiff received a leaflet of instructions for eight exercises by means of which it stated that "anybody could reduce." While the plaintiff was lying on the floor doing an exercise known as the "Tummy Flattener" the rope slipped off her feet and struck her across the eyes. The blow rendered her unconscious, detached a retina, and resulted in permanent partial loss of vision in one eye. Suit was brought against the manufacturer on the ground that there was a negligent failure to "warn or otherwise protect" the user of this product. Upon a hearing of this case by nine federal court of appeals judges, the action of the trial court in granting a summary judgment for the defendant was sustained, by a five to four decision..$^{97}$

The principal basis for the prevailing opinion was that the danger involved in the use of the "Lithe-Line" was obvious. Emphasis was placed on the simplicity of the product, and on the fact that everyone knows that rubber contracts violently when released. It was pointed out that a hammer "is not of defective design because it may hurt the user when it slips," and that there is no more duty to warn the user of this fact than of the fact that a sharp knife will cut. The prevailing opinion also asserts that the "reasonably foreseeable injury from a mishap with this rope was not great-a cut lip, bloody nose, or black eye, at the most," and that a manufacturer is required to guard only against the risk of substantial harm.

The dissenters emphasized that while it is obvious that rubber is elastic, a jury might find without being unreasonable that it was not obvious that when this exerciser was used exactly as directed, the foot strap was likely to slip, and that if it did so it would strike the tuser in the face. Accordingly they thought that a jury might find there was failure of a duty to warn, or of a duty to "otherwise protect" the plaintiff by giving instructions for a safer way to exercise, as with socks on, or in a position that would shift the path of the recoil. Reference was made to a possible need for a safer design, with the use of corrugated or flattened rubber in the footstrap. The dissenters also considered that evidence should be received, if available, concerning the frequency of similar accidents. As to the point that only minor injuries were reasonably foreseeable, the dissenters considered that any facial injury was substantial, remarking that it "would be a rare woman indeed who would willingly use

96. 247 F.2d 23 (D.C. Cir.), cert. denied, 355 U.S. 855 (1957).

97. Suit also was brought against the retailer, on warranty grounds. The court of appeals was unanimous in deciding that the retailer could not be held liable, because of a statute excluding an implied warranty of fitness in the case of the sale of an article under its patent or trade name. 
an exerciser which, without fault on her part, could give her a black eye or a cut lip or any facial injury." They observed that if any substantial injury was reasonably foreseeable, the nature and extent of the injury in the particular case need not be foreseeable to establish liability for negligence.

While the Jamieson case is a close one, it may be that undue emphasis on the latent defect rule caused the court to lose sight of the basic inquiry of whether or not an unreasonable danger was created. There is a real risk under this rule that trial court judges, when faced with a negligence of design case, will dismiss the matter without adequate consideration of the basic issue of foreseeability of injury. Thomas $v$. Jerominek ${ }^{98}$ is a case in point. There the plaintiff, suing for personal injuries, alleged that the Studebaker car manufactured by the defendant was constructed in an unusual, unorthodox and unsafe manner

in that the right rear door thereof was hinged at the rear side of said door, rather than being hinged at a door post at the middle of said automobile, and in that there was built or constructed on the inside of said right rear door two silver plated handles, the function of one of which was to open and close said door and the other of which was to open and close the window of said door, but the said handles were so similar in appearance and construction that a person unfamiliar with their construction or purpose, such as the plaintiff, and in the absence of any label or notice, would not be reasonably warned or apprised of their respective individual functions. ${ }^{99}$

It would seem that this complaint, if supported by testimony as to frequent accidents and a contrary practice of other manufacturers, might well create a case for the jury. The trial judge, however, dismissed the complaint without discussion, on the ground that the plaintiff "complained of nothing which relates to the existence of a latent defect or a concealed danger." While the alleged defect was apparent, the danger may well have been less apparent. ${ }^{100}$ Doubtless, however, many courts, apprehensive that a jury will be too inclined to find liability even though the design created no unreasonable danger of the harm that occurred, will continue to invoke the latent defect rule as a questionable means of protecting the manufacturer from a prejudiced verdict.

Manufacturer's Instructions to Use in Dangerous Way. Even though a design involves only what ordinarily would be regarded as an obvious danger,

98. 8 Misc. 2d 517, 170 N.Y.S.2d 388 (Sup. Ct. 1957).

99. Id. at 518,170 N.Y.S.2d at 389.

100. The decision in the Thamas case is supported, however, by Amason v. Ford Motor Co., SO F.2d 265 (5th Cir. 1935) (applying Georgia law) (plaintiff flung to pavement and killed by following car when he opened a door hung at the rear instead of the front side in a moving car; held that car not defective and plaintiff in any event barred by contributory negligence). It has been noted in connection with this case that "notwithstanding the fact that the court could find no negligence in the design of a front door hanging at the rear, all American manufacturers subsequently changed the design of automobiles in this respect." Katz, Liability of Automobile Mamufacturers for Unsafe Design of Passenger Cars, 69 HARv. L. REv. 863, 873 n.51 (1956). Recent advertisements, however, illustrate some tendency to revert to rear-hung doors. 
recovery may be allowed on the ground that when used as directed by its manufacturer a product becomes unreasonably dangerous. This point is illustrated in Wichman v. Allis Chalmers $M f g$. Co., ${ }^{101}$ a case involving a RotoBaler, designed to make cylindrical bales of hay. The pilot machine was built in 1941, and after several variations had been tested on farms, commercial production was begun in 1946. The baler was mounted on a single axle, preceded by a seven-foot chute sliding over the ground on skids. On the chute a conveyor belt picked up the windrowed hay and carried it to some rollers and other parts mounted above the axle. The rollers compressed the hay into a thin mat, which was propelled into a cylinder and automatically wrapped with twine. Occasionally the twine failed to engage with the rollers because there was an insufficient supply of hay. It then became necessary for the operator to leave his seat on the tractor and push the twine into contact with the rollers by tossing or placing some hay against them.

In this case the plaintiff, an employee of the purchaser, was told by the manufacturer's representative to make the twine engage by standing on the frame of the machine and pushing the twine into contact with the rollers by means of some hay held in his hand. He did this successfully a number of times, but on the day of the accident the hay carried his hand into the rollers. This caused him to fall on the conveyor belt, and his leg also was drawn into the rollers. It was asserted in a suit against the manufacturer that there was negligence of design in failing to equip the baler with a protective shield over the rollers, and in giving improper directions and assurances of safety as to the manner in which the operator might cause the twine to become re-engaged with the rotating rollers. The trial court, sitting without a jury, found negligence in both respects and freedom from contributory negligence on the part of the plaintiff.

On appeal, the manufacturer relied on an earlier decision involving the same machine, Yaun v. Allis-Chalmers $M f g$. Co., ${ }^{102}$ where the injured operator was attempting to engage the twine by tossing hay at the rollers. There also the operator fell on the conveyor belt, and his arm went through the rollers. The court had set aside a jury finding of negligence of design, principally because "the danger from the rollers was apparent."103 In the Wicham case, however, the court distinguished the earlier decision by emphasizing the finding that the manufacturer's agent had given specific directions and assurances of safety. It was held that the trier of fact could reasonably find that "in relation to

101. 117 F. Supp. 857 (W.D. Mo. 1954), rev'd, 220 F.2d 426 (8th Cir.), cert. denied, 350 U.S. 835 (1955).

102. 253 Wis. 558,34 N.W.2d 853 (1948).

103. Evidence to the effect that the rollers on harvesting machines were guarded by a shield or hood was held to have been improperly admitted because the rollers on harvesters were closer together than those on bailers. Even though an official of the state industrial commission testified that a hood of the type used on harvesters and combines would have prevented the accident and that the machine to be safe "must be equipped with a quickstopping device," this testimony was regarded as insufficient to establish negligence. 
such instructions" the defendant "ought reasonably to have equipped the rollers with some shield or guard," and that the manufacturer's directions and assurances were "not so obviously glaring and dangerous" that it must be held as a matter of law that "a normally prudent person would have refused to rely on them."104

Representation of Safety. Another factor, besides improper directions for use, which tends to keep a danger from being obvious is the presence of an assurance or representation of safety by the manufacturer. ${ }^{105}$ An illustration of this point is provided by Crist $v$. Art Metal Works, ${ }^{106}$ a case involving a toy revolver which discharged a shower of sparks when the trigger was pulled. It was asserted in advertising matter that this toy was "absolutely safe" for use by children. While it was being used by a child the sparks ignited some whiskers or soft cotton material on a Santa Claus suit which he was wearing, and serious burns resulted. It was urged that since only "cold sparks" were emitted from the pistol, no unreasonable danger was involved. A majority of the court, however, found that the advertising matter accompanying the product might induce its use "in such a manner as to make an otherwise harmless article a source of danger," and that where a manufacturer markets the product with "sweeping and unqualified representations that a child could not be hurt by it" the plaintiff is entitled to go to the jury on the negligence issue. ${ }^{107}$

104. The reversal of the judgment for the plaintiff was because of an erroneous weighing of the defendant's testimony that the improper directions were not in fact given to the plaintiff.

The same point is made in another case decided the same year and apparently involving the same machine. De Eugenio v. Allis-Chalmers Mfg. Co., 210 F.2d 409 (3d Cir. 1954) (applying New Jersey law). There the operator was told by the manufacturer's representative to walk near the front of a bailer which was lunging and not working properly, and toss the accumulated hay into the chute. The operator was struck by the chute, knocked off balance, and carried up the conveyor to the rollers, losing his arm. In refusing to set aside the jury's finding of negligence the court stated, "Although there may have been no duty to warn the plaintiff to stay clear of the chute, manifestly there was a duty to refrain from directing him to place himself there by representations that only by so doing could the baler be made to do its work." Id. at 413 . It thus appears that the latent defect rule may not protect a manufacturer who gives negligent directions for use. It should be recalled, however, that in the Jamieson case the court found that the danger was too obvious for recovery even though the plaintiff was using the "Lithe-Line" there involved in the way directed.

105. 2 HARPER \& JaMres $\$ 28.7$, at 1548 .

106. 230 App. Div. 114, 243 N.Y. Supp. 496 (1930).

107. 243 N.Y. Supp. at 498-99. Likewise where a quite different product, dried milk subject to deterioration, was involved it was held that the case of an infant made ill by the milk should have been submitted to the jury because of the manufacturer's representations. Counsel for the defendant pointed out that there was no evidence that the powder at the time of consumption was still in the same condition as when it was purchased, and insisted that "it is well known that dried milk products are subject to deterioration if not properly cared for after leaving the hands of the manufacturer." The court found, however, that a negligence issue was created by the manufacturer's representations on labels and circulars that the product was "absolutely safe" with no suggestion anywhere "that the product is subject to deterioration from any cause." Rosenbusch v. Ambrosia Milk Corp., 181 App. Div. 97, 101, 168 N.Y. Supp. 505, 508 (1917). 
A quite recent case on this point involves harm to cattle from a chemical weed killer. ${ }^{108}$ This chemical, in killing some willow trees, drew nitrates from the soil into their leaves, which were made salty and attractive to cattle by the spray. In upholding a finding of negligence, the court emphasized representations by the manufacturer's agent that the weed killer could be used at this point without moving out the cattle, and statements on each bag of the chemical that it was "not hazardous to livestock." It was observed that an assurance of safety may well create an unreasonable danger of the harm it operates to conceal.

In the cases just considered there was no warning of any sort. Where the manufacturer does give a warning, the accompanying representations of safety still may help to create an issue for the jury as to the adequacy of the warning. This point was made in a case involving some cleaning fluid containing carbon tetrachloride. ${ }^{100}$ There was a warning on two sides of the can, in small letters, reading: "Caution. Do not inhale fumes; use only in well-ventilated places." On all four sides of the can, however, in large letters, were the words "Safety-Kleen." A housewife who used the product in cleaning her home died from inhalation of the fumes. The court upheld a finding that the product was unreasonably dangerous, stating, "The word 'safety' was so conspicuously displayed on all four sides of this can of dangerous fluid as to make the word 'Caution' and the admonition against inhaling fumes and as to use only in a well-ventilated place seem of comparatively minor import."110 In a later case involving death from carbon tetrachloride fumes the jury was permitted to find that the warning was insufficiently prominent even in the absence of any assurance of safety.111

Sufficiency of Warning to Make Design Safe. In some cases a design which involves an unreasonable risk remains unsafe in spite of a warning. Suppose, for example, that a dress manufacturer markets an evening dress with nitrocellulose sizing which is so inflammable that the garment is apt to burst into flames when touched by a lighted match or cigarette. There are two cases where the manufacturer has been held liable in this situation. ${ }^{112}$ Apparently

108. La Plante v. E.I. du Pont de Nemours \& Co., 346 S.W.2d 231 (Mo. App. 1961), discussed at note 125 infra. The opinion quotes from 2 HARPER \& JAMEs $\$ 28.7$ on this matter, and likewise relies on 1 FRUMER \& FrIEDMaN \$ 8.05[2].

109. Maize v. Atlantic Ref. Co., 352 Pa. 51, 41 A.2d 850 (1945).

110. Id. at $55,41 \mathrm{~A} .2 \mathrm{~d}$ at 852 .

111. Tampa Drug Co. v. Wait, 103 So. $2 d 603$ (Fla. 1958), discussed in 1 FrUMer \& FRtedMan $\$ 8.05[3]$.

112. Dayton v. Harlene Frocks, Inc., 274 App. Div. 1015, 86 N.Y.S.2d 614 (1948), aff'd, 299 N.Y. 609, 86 N.E.2d 176 (1949); Noone v. Fred Perlberg, Inc., 268 App. Div. 149, 49 N.Y.S.2d 460 (1944), aff'd, 294 N.Y. 680, 60 N.E.2d 839 (1945). There also have been a number of successful suits against retailers in inflammable dress cases, based on breach of implied warranty of fitness. See, e.g., Frank R. Jelleff, Inc. v. Braden, 233 F.2d 671 (D.C. Cir. 1956) ; Deffebach v. Lansburgh \& Bros., 150 F.2d 591 (D.C. Cir.), ccrt. denied, 326 U.S. 772 (1945) ; Chapman v. Brown, 198 F. Supp. 78 (D. Hawaii 1961); Ringstad v. I. Magnin \& Co., 39 Wash. 2d 923, 239 P.2d 848 (1952). 
in neither case was any warning given of the highly combustible nature of the dress. It would seem, however, that a dress so designed creates an unreasonable risk even though accompanied by a warning. Such a garment is made not for wear in a church or other place where smoking is quite unlikely, but for use at social functions where smoking and lighted matches are to be expected. If the dress is purchased, this means that in all probability the warning is not being taken seriously. It would seem, therefore, that a jury might find that a design of this type creates an unreasonable hazard even though a warning is present, particularly if a comparable dress could be made by use of material less likely to envelope the user in flames.

A similar situation was presented where a crop-dusting chemical, designed to kill plants with broad leaves appearing in rice fields, drifted to cotton fields and damaged the broadleafed cotton. The manufacturer in this case published and circulated a warning of the risk of damaging cotton and other broadleafed crops, but nevertheless was held liable. The actual basis for the decision was that no sufficient test had been made as to the floating qualities of the dust, and that under these circumstances the manufacturer should be held strictly liable for what was regarded as an ultra-hazardous enterprise. ${ }^{113}$ The facts of the case seem to present, however, a negligence issue and it may well be that a product involves an unreasonable risk if it is apt to drift and harm valuable crops, even though there is a full and complete warning of the danger. ${ }^{114}$

More frequently, perhaps, the effect of a warning is to make adequate a design which would otherwise present an unreasonable risk. ${ }^{115}$ This point is illustrated by Foster v. Ford Motor Co., ${ }^{116}$ where the plaintiff alleged that a farm tractor was negligently designed. It appeared that most of the weight was at the rear, with the result that when the machine mired and heavy power was applied, the tractor was likely to up-end and fall over backwards on top

113. Chapman Chemical Co. v. Taylor, 215 Ark. 630, 222 S.W.2d 820 (1949). A recent crop spraying case holds the landowner strictly liable for crop-spraying by an independent contractor, referring to the risk of accidents on neighboring crops notwithstanding the exercise of utmost care, and finding that "the rule of nondelegability followed in the socalled inherently-dangerous-activity negligence cases ... applies with equal or greater force to the conduct of extra hazardous activity." Loe v. Lenhardt, 362 P.2d 312, 318 (Ore. 1961).

114. See Noel, Manufacturers of Products-The Drift Touard Strict Liability, 24 TENN. L. Rev. 963, 981 (1957). In a later case where the same weed killer 2-4-D, was used not in dust form but mixed with oil and as a result was more subject to control, it was held that there was no basis for strict liability and that a finding by the jury that the manufacturer was not negligent was supported by the evidence. Walton v. Sherwin-Williams Co., 191 F.2d 277 (Sth Cir. 1951) (applying Arkansas law). Several of the cases where the manufacturer who is watching his costs too closely fails to provide a commonly used safety device, such as an automatic cutoff on a vaporizer to prevent overheating, also seem to present a situation where the risk would remain unreasonable even where the product is accompanied by a warning. See 2 HARPER \& JAMres $\S 28.3$ n.5.

115. 2 HARPER \& JAMtes $\S 28.3$.

116. 139 Wash. 341, 246 Pac. 945, Annot., 48 A.L.R. 934 (1926). 
of the operator, as it did in this case. The instructions with the product, however, warned against this danger and of the need for releasing the clutch at once if the front end should start to lift. In holding that there was no sufficient evidence of negligence, the court emphasized that the danger was present only when tremendous power was applied, and that "notice of the dangerous character of the tractor under such conditions was fully set out in the Manual of Instructions." 117

It should be borne in mind that while a warning to the purchaser of a product may prevent his own recovery, 118 the manufacturer still may be liable for negligence of design to others whom he should expect to use the product, or to be in the vicinity of its probable use. As to such persons, the product still may be unreasonably dangerous. ${ }^{119}$ This point seems to be involved in the decision considered earlier involving the gas refrigerator which emitted carbon monoxide gas unless the burner was regularly cleaned. Perhaps if the original purchaser of the refrigerator had been adequately warned of a necessity of cleaning the burner, the article would not have been held unreasonably dangerous to him. Since, however, there were no directions or warnings attached to the product, it seems clear that any separate warning distributed only with a new refrigerator would be inadequate for a plaintiff who was a second-hand purchaser. In holding that a jury could find negligence of design, the court pointed out that the refrigerator was a durable product, so that the defendant could readily foresee that it might pass into the hands of a secondhand user. . $^{120}$

It thus appears that in some cases a design will continue to be dangerous unless the warning is attached to the product itself in some way. Furthermore, even a warning attached to the product would not be sufficient to protect the defendant with respect to those who merely are apt to be in the vicinity of the probable use of the chattel when the intervening carelessness

117. Id. at $347,246 \mathrm{Pac}$. at 947 . The same result was reached by another court a few years later with respect to an accident of the same kind with the same type of tractor. Ford Motor Co. v. Wolber, 32 F.2d 18 (7th Cir.), cert. denied, 280 U.S. 565 (1929) (applying Illinois law).

Many other cases, dealing primarily with the duty to warn, could be cited to show how a design may be regarded as reasonably safe only if accompanied by an adequate warning. See generally 2 HARPER \& JAMES $\$ 28.7 ; 1$ Frumer \& FrIEDMAN $\$ \$ 8.01$ to -.06 .

In one of the more recent cases a workman was restringing a cable on a portable grain elevator, a process occasionally necessary. He erroneously assumed that some "stop hooks" were intended to support a heavy tube in fact supported only by the cable and was killed when the tube fell on him. It was held that a jury could find the manufacturer negligent in failing "to apprise the purchasing public either by labels or instructions as to the manner in which the article may be safely used" and to warn of "the dangers arising out of the process of restringing the cable." Johnson v. West Fargo Mfg. Co., 95 N.W.2d 497, 501 (Minn. 1959).

118. 2 Restatement, ToRts $\S 398$, comment $b$ (1934).

119. Id. at $\$ 389$.

120. Beadles v. Servel, Inc., 344 I1l. App. 133, 100 N.E.2d 405, 411 (1951), discussed at text accompanying note 68 supra. 
of the owner of the product is foreseeable. ${ }^{121}$ Insufficient recognition seems to have been given to this principle in Scurfield v. Federal Laboratories, Inc., ${ }^{122}$ a case involving a tear gas gun made to look like a fountain pen, with the clasp serving as a trigger. A customer picked up this innocuous looking article for inspection and accidentally discharged the tear gas into his own face. It was held that there was no substantial evidence of negligence on the part of the manufacturer, since the purchaser was fully informed of the nature of the article, and it could not be foreseen that the sale of the gun involved any probability of injury to customers of the purchaser. It appeared, however, that the defendant's agent had advised that the gun be kept in readiness on the purchaser's desk. Under these circumstances, it would seem that unless equipped with some safety appliance the gun might constitute an unreasonable hazard to those likely to be in its vicinity. A warning to the purchaser might well make the design safe as to him, but as a dissenting opinion in the case points out, it was not unforeseeable that a normally inquisitive person might pick up the gadget to examine it. It is quite likely that many courts would have let this case go to the jury on the issue of whether the warning was sufficient with reference to persons other than the purchaser.

\section{FaILURe to Foresee}

The problem of determining whether a certain type of design renders harm likely to occur is matched by the problem of determining whether the manufacturer was in a position to foresee the likelihood of such harm. In the field of manufacturers' liability questions of foreseeability are closely entwined with the status of the defendant; as a manufacturer he is held to the knowledge and skill of an expert in his field. Aside from questions of purely professional foreseeability some special problems have arisen in design cases with regard to the foreseeability of injuries from unintended uses of the product, from fire, and from allergic reactions.

\section{The Manufacturer as Expert}

The point that anyone who enters a special field of manufacturing will be held to possess the knowledge and skill of an expert in that field and must "keep reasonably abreast ... of techniques and devices used by practical men in his trade"123 is effectively made in a case involving a large tank for liquefied gas. ${ }^{124}$ The tank had been made in cylindrical rather than spherical form after the defendant manufacturer expressed confidence that cylindrical tanks

121. See 2 Restatearent, Torts $\S 388$, comment $d$ (1934).

122. $335 \mathrm{~Pa} .145,6$ A.2d 559 (1939).

123. See 2 HARPER \& JAMres $\$ 28.4$, cited with approval in Wright v. Carter Prods., Inc., 244 F.2d 53 (2d Cir. 1957) (applying New York law); Martin v. Bengue, Inc., 25 N.J. 359, 371, 136 A.2d 626, 632 (1957) ; Braun v. Roux Distrib. Co., 312 S.W.2d 758 (Mo. 1958). See also 1 Frumer \& FriedMan $\$ 8.01$.

124. Moran v. Pittsburgh-Des Moines Steel Co., 183 F.2d 467, 469-70 (3d Cir. 1950) (court sitting in Pennsylvania applying Ohio law). 
"will be just as satisfactory as the spheres have been and we feel that they should be preferred because of the saving in cost." This prediction proved to be far from correct; one of the tanks ruptured about a year after it had been filled, and the resulting fire and explosions took the lives of over one hundred persons and injured many more. In response to an assertion of negligence of design the defendant showed that there was no established usage in favor of the spherical shape. Since, however, there was testimony that "reasonable persons of the skill the defendants held themselves out to possess would not have constructed a tank of cylindrical form in this situation," a jury finding of negligence was sustained. ${ }^{125}$

In the determination of whether or not a manufacturer in fact has exercised the care and skill of an expert several matters are to be considered. One of the most significant factors, although the liquefied gas case shows that it is not conclusive, is whether others in the field are using the same design, or a safer design. Other factors to be considered are whether a safer design not yet in use is known to be feasible, and whether, in the case of a new product, there has been adequate testing. These matters can best be considered separately.

Use by others of same design. It has been shown that extensive safe use of the same design tends to show the absence of any unreasonable danger. ${ }^{120}$ The point now to be considered is that use of the same design by other manufacturers also tends to show that the defendant has kept abreast of scientific techniques and safety devices used by other experts in the same field. This matter is brought out in Watts v. Bacon \& Van Buskirk Glass Co., ${ }^{127}$ where glass supplied by the defendant for the front door of a drug store broke into sharp pieces as a customer was opening the door, with resulting injuries. It appeared that after consultation with the defendant the owner of the store had decided to use plate glass rather than the more expensive tempered glass specified by his architect. The plaintiff contended that plate glass was unsuitable for the door, introducing evidence that tempered glass is five times stronger than plate glass and that when tempered glass is broken the pieces have rounded rather than jagged edges. The intermediate court thought that this amounted to substantial evidence of negligence of design, ${ }^{128}$ but the Supreme Court reinstated a directed verdict for the defendant supplier, chiefly because it appeared from the record that "plate glass installation was customary and usual while the use of tempered glass was exceptional."120

125. Id. at 470. A quite recent case goes so far as to allow a jury to place on a manufacturer of a chemical used to kill willow trees a duty to realize that this product, in causing the death of the willows, might draw from the soil nitrates in such amounts as to endanger cattle, particularly since the spray left a salty residue on the leaves making them particularly attractive to cattle. La Plant v. E.I. du Pont de Nemours \& Co., 346 S.W.2d 231 (Mo. App. 1961), discussed at text accompanying note 108 supra.

126. See text accompanying notes 60-64 supra.

127. 18 I1l. $2 \mathrm{~d} 226,163$ N.E.2d 425 (1959).

128. 20 I11. App. 2d 164, 155 N.E.2d 333 (1958).

129. 18 I11. $2 \mathrm{~d}$ at 231,163 N.E.2d at 428. Cf. Genell, Inc. v. Flynn, 348 S.W.2d 196 
A number of other decisions likewise emphasize the use by other manufacturers of the same design as an almost conclusive indication that the requisite expert knowledge and skill has been employed. So where the operator of a tractor was injured from contact with an exposed, rapidly turning universal joint between his tractor and a threshing machine to which it was attached, and the plaintiff claimed that the joint should have been shielded, the court ruled that there was no substantial evidence of negligence of design, partly because of the character of the defect, but also because at the time of the accident, in 1937, so far as shown by the evidence, no device to enclose the middle universal joint had been devised or shown to be practical. ${ }^{130}$ Likewise when a child was badly burned by the contents of an overturned vaporizer, it was held that the presence of a loose and easily removable lid did not furnish substantial evidence that the vaporizer was negligently designed, since "the evidence discloses that the vaporizer was of a standard and conventional type and design." 131 In Amason v. Ford Motor Co., ${ }^{132}$ where a car door was hinged at the rear instead of at the front, the court, in deciding for the defendant, took judicial notice "that thousands of passenger automobiles in daily use have their doors hinged at the rear." ${ }^{133}$ In a recent decision involving the adequacy of a safety mechanism on a rifle, alleged to move too easily from a "safe" to a "fire" position, the court admitted not only testimony that other makers of guns used the same device, but also testimony as to the good reputation of the other manufacturers who used the same mechanism. ${ }^{134}$ The reputation of these other manufacturers seems clearly relevant to the issue of whether or not the defendant used the care and skill of an expert, as well as to the unreasonable danger issue on which it actually was admitted.

While the cases clearly indicate that use by others of the same design tends to negative an allegation of negligence, this evidence is not always conclusive. As stated by Justice Holmes, "What usually is done is evidence of what ought

(Tex. Civ. App. 1961) (landlord held liable for injuries resulting when glass portion of door gave way while being pushed by a child).

130. Stevens v. Allis-Chalmers Mfg. Co., 151 Kan. 638, 100 P.2d 723, 726 (1940).

131. Blissenbach v. Yanko, 90 Ohio App. 557, 561, 107 N.E.2d 409, 411 (1951), discussed at text accompanying note 31 supra. See also Marko v. Sears, Roebuck \& Co., 24 N.J. Super. 295, 299, 94 A.2d 348, 349 (1953), noted in 39 VA. L. REv. 698 (1953) (testimony that no other power mowers had the shield which plaintiff had alleged was essential for safety); Reusch v. Ford Motor Co., 196 Wash. 213, 82 P.2d 556 (1938) (testimony that a gasoline in-take pipe alleged to be of improper design with reference to the risk of escape of sparks from the muffer and exhaust was "in general use").

132. 80 F.2d 265 (5th Cir. 1935) (applying Georgia law).

133. Id. at 266. So also where it was alleged that an overhead door for a building was improperly designed in not having a device to prevent it from falling on the plaintiff during installation, the court emphasized, in holding that a verdict for the plaintiff was properly set aside, that there was no evidence that at the time of the accident there was "a safer or better design commonly in use in the industry" and that the defendant's design was in customary use. Day v. Barber-Coleman Co., 10 IIl. App. 2d 494, 507, 135 N.E.2d 231, 238 (1956).

134. Lopez v. Heesen, 365 P.2d 448 (N.M. 1961). 
to be done, but what ought to be done is fixed by a standard of reasonable prudence, whether it usually is complied with or not."135 This principle has been applied in the field of products design in Northwest Airlines, Inc. $v$. Glenn L. Martin Co. ${ }^{136}$ where the court said,

the fact that Northwest conformed to the practice of other airlines in failing to equip No. 44 with radar did not establish its exercise of ordinary care as a matter of law. Customary practice is not ordinary care; it is but evidence of ordinary care. ${ }^{\mathbf{1 3 7}}$

Consequently even though a manufacturer is able to show that all others in the field have used the same design, the court may in some cases hold that an entire industry has been lacking in ordinary care. ${ }^{138}$ Even where there exists a statutory requirement that some particular safeguard be provided, compliance may mean only that the defendant has met a minimum standard; it does not conclusively establish that due care has been exercised. ${ }^{139}$

Use by Others of Safer Design. Sometimes the defendant manufacturer, instead of following an industry practice as in the cases just considered, has used a design which differs from the one commonly employed, and has fewer safety characteristics. In such a case, the customary use of the safer design clearly is relevant evidence to establish that the defendant's design involves both unreasonable danger and a failure to exercise the skill of an expert. This point is brought out in the cases where the defendant's product lacks some customary safety device. ${ }^{140}$ It also may be illustrated by Darling $v$. Caterpillar Tractor Co., ${ }^{141}$ a case involving a hinged inspection cover on the back of a bulldozer. When the plaintiff stepped on the cover, which was latched shut, it gave way on the hinged side and injuries resulted. The plaintiff's experts testified that accepted procedure was to eliminate stress on the hinge by extending the deck plate lip either all the way around the deck cover, or along the full length at the side opposite the hinge, for otherwise if the hinge broke the latch would not remain locked, but would slide out. In upholding a verdict for the plaintiff the court stated that it could have been found that the accident resulted partly, at least, from negligence of design, stating that it "was a question for the jury whether a simple change in the deck plate was required

135. Texas \& P. Ry. v. Behymer, 189 U.S. 468,470 (1903).

136. 224 F.2d 120 (6th Cir. 1955), Annot., 50 A.L.R.2d 882 (1955), cert. denied, 350 U.S. 937 (1956) (applying Ohio law), discussed at text accompanying note 158 infra.

137. Id. at 129. The court was referring to the situation in 1948. See also Cadillac Motor Car Co. v. Johnson, 221 Fed. 801, 804 (2d Cir. 1915); Katz, Liability of Automobilc Manufacturers for Unsafe Design of Passenger Cars, 69 HARv. L. Rev. S63, 865 (1956).

138. Cf. The T. J. Hooper, 60 F.2d 737, 740 (2d Cir. 1932) (applying New York law), where Judge Learned Hand points out that "a whole calling may have unduly lagged in the adoption of new and available devices."

139. See 1 Frunier \& FrIEdMan $\$ 8.07$; St. Louis-San Francisco Ry. v. Fowler, 195 Ark. 122, 128, 111 S.W.2d 546, 549 (1937).

140. See text accompanying notes $29-47$ supra.

141. 341 P.2d 23 (Cal. App. 1959). 
in reasonable anticipation of the failure of the weld for one cause or another."142 It is apparent that the defendant's failure to follow an accepted safety procedure in the design of the inspection cover was a significant factor in the decision. ${ }^{143}$

This decision and others like it do not mean that the manufacturer may not be able to show, in some cases, that his product was reasonably safe even though he has departed from customary usage. It has been stated that proof of variance by the defendant from the ordinary usage and practice "does not in itself establish negligence, since such a rule would make one responsible for not adopting the most recent improvements and devices when another might be safely employed."144 Where, however, the plaintiff's testimony shows not only that the defendant's design is different from that ordinarily employed, but is less safe, the jury is of course quite likely to find an unreasonable danger. There may even be a duty to withdraw from the market or redesign models lacking safety features which have become standard in the industry, on the ground that the original design now creates an unreasonable risk.

Occasionally testimony concerning failure to follow the customary practice has been regarded as not providing any substantial evidence of negligence of design because of emphasis on the obvious character of the danger, as in the case where the handles opening the door and the window of a passenger automobile are unusually similar, ${ }^{145}$ or where the door in a passenger car is hung at the rear in an unorthodox manner. ${ }^{146}$ Furthermore, some courts have been rather strict in insisting that the general practice departed from be one used in an almost identical type of machine. ${ }^{147}$ Finally, where the plaintiff is unable to show a general practice of using a safer design than that employed

142. Id. at 30 .

143. See also Mruller v. A.P. Kirschbaum Co., $298 \mathrm{~Pa} .560$, 148 At1. 851 (1930) (coffee urn lacked reducing valve "customarily provided in similar construction"); Garbutt v. Schecter, 167 Cal. App. 2d 396, 334 P.2d 225 (1959) (design of easily upset modernistic chair represented "a wide departure from the standards of chair construction"); Clark v. Zurich Truck Lines, 344 S.W.2d 304 (Mo. App. 1961) (steering mechanism designed by method of manufacture which departed from that recommended as the best in the Standard Automobile Engineer's Handbook).

144. Muller v. A.P. Kirschbaum Co., 298 Pa. 560, 564, 148 At1. 851, 853 (1930). In a recent case involving a die casting machine there apparently was a variance from customary procedure in using a free floating spool in a valve without springs on either side. The court held that this case should have been submitted to the jury, but only after testimony by a professor of engineering that this construction constituted negligence of design, on the ground that it resulted in vibration which could cause the spool to shift in a dangerous way. Robinson v. Reed Prentice Corp., 286 F.2d 478 (9th Cir. 1961) (applying California law).

145. Thomas v. Jerominek, 8 Misc. 2d 517, 170 N.Y.S.2d 388 (Sup. Ct. 1957), discussed at text accompanying note 98 sipra.

146. Amason v. Ford Motor Co., 80 F.2d 265 (5th Cir. 1935) (applying Georgia law).

147. See, e.g., Stevens v. Allis-Chalmers Mfg. Co., 151 Kan. 638, 100 P.2d 723 (1940); Yaun v. Allis-Chalmers Mfg. Co., 253 Wis. 558, 34 N.W.2d 853 (1948), discussed at note 103 supra. 
by the defendant, there may be difficulty in introducing testimony about the safer design, even though it is employed by some other manufacturers. Thus in Day v. Barber-Colman Co., ${ }^{148}$ a case involving an overhead door which fell on the plaintiff during installation, the plaintiff's expert testified that if the door were equipped with a staggered lift chain, its fall would be broken, and the design would have been more safe. There was no evidence, however, that doors with staggered lift chains were "in common or accepted use in the industry." Under these circumstances it was held that a verdict for the plaintiff was properly set aside, and that testimony as to other safer designs "whether in use in the industry or not" was not admissible.

This ruling seems questionable. While it is clear that the testimony concerning a safer design is less significant in a case where only a few make use of it, such testimony has some relevance on the basic issue of whether or not the defendant's design was reasonably safe. As indicated earlier, while customary practice often is ordinary prudence, that is not always the case. ${ }^{140}$ It should be added that even though a safer design is adopted by the defendant himself for later models, evidence of this fact may be excluded because of the rule that evidence of changed conditions is inadmissible. ${ }^{150}$

Should the matter be carried a step further, and the plaintiff be permitted to introduce testimony of a safer design not actually in use by anyone, but known to be feasible? Even in this situation the testimony would seem relevant to the issue of whether the defendant created an unreasonable danger, for occasionally "a whole calling may have unduly lagged in the adoption of new and available devices."151 It is undoubtedly true, as stated in the Day case, that there is no obligation on a manufacturer "to adopt every possible new device which might possibly have been conceived or invented,"162 but the jury could be instructed that a failure to use an available device does not lead to liability unless the failure to employ it makes the product unreasonably dangerous. It may be that under such instructions a jury would find a failure to use reasonable care when, for example, a conventionally designed dash. board in a passenger automobile, with its many projections against an unyielding metal background, helps produce a serious injury, even though recessed dashboards may not be in use at the time of the accident. ${ }^{153}$ While a defendant against whom such a verdict is rendered may feel that he has been dealt with severely, the verdict would serve to correct such a situation as that disclosed by the Cornell crash research group in its conclusion that "fifteen years of

148. 10 I1l. App. 2d 494, 135 N.E.2d 231 (1956), discussed at note 133 supra.

149. See text accompanying notes 137-39 supra.

150. Tyson v. Long Mfg. Co., 249 N.C. 557, 107 S.E.2d 170 (1959), discussed at text accompanying note 94 supra. There is an exception to this rule where the evidence is introduced only to show that the safer design suggested is practicable. See Boeing Airplane Co. v. Brown, 291 F.2d 310 (9th Cir. 1961) (applying Washington law).

151. The T. J. Hooper, 60 F.2d 737, 740 (2d Cir. 1932) (applying New York law).

152. 10 I11. App. $2 \mathrm{~d}$ at 508,135 N.E.2d at 238.

153. See Katz, Liability of Automobile Mannfacturers for Unsafe Design of Passenger Cars, 69 Harv. L. Rev. 863, 868, 869 (1956). 
automobile designs have produced no improvement as far as their injury potential is concerned, and the data pointedly suggests that the newer model automobiles are increasing the rate of fatalities in injury-producing accidents."154

Degree of Testing Required for New Products. Where a new product is involved, ordinarily there is of course no evidence as to use by others of the same design, or of a design that is more safe. The testimony will relate rather to the question of whether or not the manufacturer, as an expert, tested his new product sufficiently before placing it on the market.

One factor which bears closely on the adequacy of the testing is industry practice. The point may be illustrated by the Texas City disaster case, Dalehite v. United States, ${ }^{105}$ involving the explosion of fertilizer which contained ammonium nitrate. The United States was absolved from liability not only because of the determination that a discretionary function was involved, but also on the ground that no unreasonable danger was to be anticipated. It was so ruled by the Supreme Court even though the trial court had found that the fertilizer had been shipped into a congested area without adequate testing and that its dangerous properties should have been realized. Some tests had been made with respect to explosion and fire hazards, but the tests had been terminated at an intermediate stage, against the recommendation of the testing laboratory, and "in the face of the suggestion that further research might point up suspected but unverified dangers."156 Under these circumstances, even though there was evidence that private manufacturers took no more precautions than did the government, it would seem that the trier of fact could reasonably have found that there was inadequate testing. As Mr. Justice Jackson states in a vigorous dissent:

Where the risk involved is an explosion of a cargo-carrying train or ship, perhaps in a congested rail yard or at a dock, the producer is not entitled as a matter of law to treat industry practice as a conclusive guide to due care. Otherwise, one free disaster would be permitted as to each new product before the sanction of civil liability was thrown on the side of high standards of safety. ${ }^{157}$

This dissent was concurred in by two justices, but the remaining four members of the court who participated in the decision felt that there was no knowledge of any danger which was probable as distinguished from merely possible.

The above quotation suggests that another factor of special significance with reference to the amount of testing needed is the gravity of the harm threatened. A decision which gives more recognition to this factor than did the prevailing

154. Automotive Crase Injury Research Project, Cornely University Medical College Annual Report i (1955). There are indications that automobile engineers proposing safer designs are apt to be thrust aside in favor of salesmen and stylists. See statement by engineer employed by an insurance company to design a "survival car." Newsweek, May 1, 1961, p. 60.

155. 346 U.S. 15 (1953).

156. Id. at 55 (dissenting opinion).

157. Id. at 55-56. 
opinion in the Dalehite case is Northwest Airlines, Inc. v. Glenn L. Martin Co., ${ }^{158}$ involving a Martin "202" passenger plane which crashed with thirtytwo persons aboard when a wing fell off during a thunderstorm. The plane had flown only about five per cent of its expected service life. On the day of the crash, in 1948, the pilot of another plane of the same kind made a routine report of difficulty in keeping the plane in level flight. The pilot then got into his car to drive home, but fortunately changed his mind and went back to urge that the plane be carefully examined before its next trip. The examination disclosed that a joint in the right wing of the plane was broken, and that the wing was being held in place only by its "skin." The remaining twentythree planes of this type immediately were grounded, and it was discovered that four other planes had fatigue cracks at the wing joints at the place where the wings on the plane that fell had broken. Suit was brought by Northwest Airlines against the manufacturer of the plane on grounds of negligence of design, one basic allegation being that the aluminum alloy used in the wing joint had not been sufficiently tested for fatigue failure. Although there was evidence that the phenomenon of fatigue in metal was little understood at the time of this accident, the appellate court held that the case had been properly submitted to the jury as to the adequacy of the testing as well as on other negligence issues. ${ }^{159}$

Another decision which emphasizes the relation between the gravity of the harm which may result and the duty to test is O'Donnell v. Asplundh Tree Expert Co. ${ }^{160}$ There a man pruning a tree fell fifty feet to the ground when the metal hook that secured his safety belt to a climbing rope snapped, as he was making a swing to another part of the tree. It was alleged in a suit against the tree company which supplied the equipment that the hook was made of malleable rather than forged iron and was therefore of insufficient strength for the purpose for which it was supplied. The assembler of the hook and of an attached clip and spring had stated that the hook was not forged and not suitable for safety equipment, but rather was customarily used for hanging accessories on linemen's belts and for other purposes not involving critical loads. The tree company had made no tests as to the suitability of the hooks for supporting a tree clearance man.

In reversing the trial court and an intermediate appellate court, and holding that the jury could properly find negligence from the failure to test the hooks, Chief Justice Vanderbilt stated:

Reasonable care requires that the article so chosen be constructed as to perform the task to which it is dedicated. Here there was evidence that the material used, malleable iron, was not satisfactory for this particular

158. 224 F.2d 120 (6th Cir. 1955), Annot., 50 A.L.R.2d 882 (1955), cert. denied, 350 U.S. 937 (1956) (applying Ohio law).

159. The jury found negligence, but also that the plaintiff was barred by contributory negligence and voluntary assumption of risk. It was held on appeal that there was no substantial evidence of contributory fault.

160. 13 N.J. 319, 99 A.2d 577 (1953). 
job, that it was not the proper metal to be used where a man's life would depend upon its effectiveness. In effect, the defendant had assumed the liability of a manufacturer when he sold the hooks for a use never intended by the manufacturer. He was therefore under a duty to ascertain that the article was made of proper raw materials and was so manufactured as to sustain the weight of a man's body. ${ }^{161}$

It is evident that in this case, as in the Northrwest Airlines decision, the gravity of the harm likely to be suffered if the product proved to have inadequate specifications was a principal factor in the holding that the defendant could be found to have failed in a duty to inspect. ${ }^{162} \mathrm{~A}$ recent decision involving a spray cleaner containing tetrachloroetlyne which causes hepatitis likewise finds a duty, when a product contains a chemical with known possibilities of toxic effects, "to make adequate tests before putting it on sale to the public."103

\section{Special Problems of Foreseeability}

Somewhat apart from the question of what dangers a manufacturer should foresee and guard against because of his professional position are several much litigated areas of foreseeability in the products field. A particularly important area involves the duty of manufacturers to foresee intervening acts of others. While there is no obligation to anticipate abnormal uses of a product, the abnormality of a particular use may be a close question. Moreover, there ordinarily is no duty to anticipate careless use, but where the use is by a person not familiar with the dangers of the product, the matter of foreseeability of the use may be a question for the jury. A considerable number of decisions involve a second special problem - whether the manufacturer must anticipate that his product may catch fire and cause serious harm. Finally, modern decisions have imposed on manufacturers an increased duty to anticipate the

161. Id. at $338,99 \mathrm{~A} .2 \mathrm{~d}$ at 587 . This conclusion is supported by 2 REstatement, Torts $\$ 388$, comment $k$ (Supp. 1948), which places the duty of inspection on anyone who supplies a chattel for a known purpose to determine if it is fit for the special use for which it is supplied.

162. Likewise in a case where the user of a tractor relied on the steering wheel to keep him on a seat without side supports, the use of a new material of rubber and fibre composition, without adequate testing as to its strength, led to liability. Goullon v. Ford Motor Co., 44 F.2d 310 (6th Cir. 1930) (applying Kentucky law), discussed at text accompanying note 49 supra. Reasonable testing may involve a repetition of tests for diverse uses of the product. So where a spray designed to kill peach tree borers was subjected to tests in a number of states, but not in Michigan, it was held that the manufacturer could be found negligent "in distributing such product in Michigan without proper field tests having been made in this State to determine its effect on peach trees." Ebers v. General Chem. Co., 310 Mich. 261, 279, 17 N.W.2d 176, 183 (1945). Likewise the Arkansas crop dusting decision, Chapman Chem. Co. v. Taylor, 215 Ark. 630, 222 S.W.2d 820 (1949), discussed at text accompanying notes 113-14 supra, was based partly on the fact that the dust was inadequately tested for the area where it was to be used.

163. Twoubley v. Fuller Brush Co., 221 Md. 476, 158 A.2d 110, 118 (1960). 
use of his product by not only so-called ordinary users, but also those subject to allergic reactions.

Foreseeability of unintended uses. It is established that a manufacturer's liability for negligence is restricted to situations where the product is used "for a purpose for which it is manufactured."164 If the danger arises from use of the product for some purpose which could not reasonably have been foreseen by the manufacturer, it seems clear that he should not be liable. As has been observed, "A roller skate or even a book may become an instrument of serious injury if placed strategically at the top of a flight of stairs in the dark." 105 The problem is to determine whether or not the use of the product involved was in fact so unintended and unforeseeable that the case should be taken from the jury. The same principle that there is no duty on the manufacturer to anticipate unusual uses has been applied in a number of cases involving defects in the individual product, as distinguished from inadequacies of design. ${ }^{166}$

In some of the cases the unusual use of the product is so clear that a verdict is apt to be directed for the defendant on that ground. So where shoes suitable for ordinary wear are worn by someone they do not fit, it seems clear that the manufacturer should not be liable for resulting injury to the feet. ${ }^{107}$ Likewise where a housewife used the defendant's alkaline product "Calgonite," designed for automatic dishwashers, rather than its water softener "Calgon" in water used to wash venetian blinds, she could not recover for harm from alkaline burns, partly because of an adequate warning on the "Calgonite" against contact with the hands, but also because the plaintiff "used the product for a purpose not included among those recommended by the defendant."1B8

There are a few composition or design cases where the issue of whether or not the use was foreseeable has been left to the jury. So in Zesch v. Abrasive Co., ${ }^{169}$ the defendant had made a somewhat fragile grinding wheel, intended

164. 2 Restatement, ToRts $\$ 395$ (1934).

165. 2 HARPER \& JAMES $\$ 28.6$.

166. Odekirk v. Sears, Roebuck \& Co., 274 F.2d 441 (7th Cir. 1960) (applying Illinois law); International Derrick \& Equip. Co. v. Croix, 241 F.2d 216 (5th Cir.) (applying Texas law), cert. denied, 354 U.S. 910 (1957). Cf. Borg-Warner Corp. v. Heine, 128 F.2d 657 (6th Cir. 1942) (applying Michigan law) ; Mannsz v. Macwhyte Co., 155 F.2d 445 (3d Cir. 1946) (applying Pennsylvania law); Schfranek v. Benjamin Moore \& Co., 54 F.2d 76 (S.D.N.Y. 1931); Cohagan v. Laclede Steel Co., 317 S.W.2d 452 (Mo. 1958).

167. Cf. Dubbs v. Zak Bros. Co., 38 Ohio App. 299, 175 N.E. 626 (1931). This suit was against the retailer; the nonliability of the manufacturer would be more evident.

168. Shaw v. Calgon, Inc., 35 N.J. Super. 319, 332, 114 A.2d 278, 285 (1955). See also Pabellon v. Grace Line, Inc., 94 F. Supp. 989 (S.D.N.Y. 1950) (manufacturer of detergent not liable for explosion which resulted only after user mixed detergent with other chemicals) ; E.I. du Pont de Nemours \& Co. v. Ladner, 221 Miss. 378, 73 So. $2 \mathrm{~d} 249$ (1954) (manufacturer of food for hogs and poultry not liable when processor sold product, in disregard of manufacturer's warning, for use as cattle food). Cf. O'Donnell v. Asplundh Tree Expert Co., 13 N.J. 319, 99 A.2d 577 (1953) (supplier of a hook designed for use as harness equipment not liable when hook used to support man pruning trees).

169. 354 Mo. 1147, 193 S.W.2d 581 (1946). 
to cut metal with its edge. If used so as to bring stress on the side of the wheel, or if the side was used for grinding, the wheel was likely to burst or shatter. It did shatter, and the jury, which in this case found for the defendant, was held to have been properly instructed that the verdict should be against the plaintiff if his use of the wheel was "in a manner or for a purpose for which it was not designed." On the other hand, recovery was allowed where a woman was injured when part of an aluminum chair on which she was standing to reach a cupboard gave way. The chair had a U-shaped base and tended to tip forward when weight was placed near the front, but the court said that it could be reasonably anticipated that the chairs would "be used for ... standing upon them."170 Likewise, where a woman wears a highly inflammable cocktail dress near a kitchen stove, a jury could find that this use was foreseeable. ${ }^{171}$

There are many other cases where the foreseeability of the particular use might have been left to the jury, but the court nevertheless has found the use to be unusual as a matter of law. Some of these cases are discussed later in connection with the foreseeability of harm from fire. ${ }^{172}$ One of the more representative decisions involves some steel casements manufactured by the defendant for use in a chapel. ${ }^{173}$ The crossbars on the casements, intended to support glass, were about two feet apart and made of one-eighth inch steel. It was alleged that the crossbar was inadequately fastened to the upright part of the casement, with the result that a workman fell to his death when he used the crossbar either as a handhold or as a footrest. In taking the case from the jury the court stated that the casements were designed simply to support glass windows, that they were safely designed for that purpose, and that there was no negligence in failing to manufacture a casement so that it could be "used safely as a ladder by an employee weighing about one hundred sixty or one hundred seventy pounds." It was decided that this "was an entirely different use than that for which the casements were manufactured." There was testimony that it was common practice for iron and steel workers to climb up and down the casements, but the court discounted this evidence since there was no showing that the defendant knew of the practice, or that it was so general as to charge the defendant with notice. It may be, however, that even in the absence of notice, a jury could properly find that this use of the casements was foreseeable, particularly if the crossbars appeared to be more firmly affixed than was in fact the case. If so, the design might be unsafe without a warning.

170. Phillips v. Ogle Aluminum Furniture, 106 Cal. App. 2d 650, 654, 235 P.2d 857, 859-60 (1951).

171. See Ringstad v. I. Magnin \& Co., 39 Wash. 2d 923, 239 P.2d 848 (1952). This action was against the retailer, for negligence and breach of warranty. The negligence count was dismissed because the retailer, unlike the manufacturer, had no reason to know that the dress was almost explosively inflammable.

172. See text accompanying notes 196-209 infra.

173. McCready v. United Iron \& Steel Co., 272 F.2d 700 (10th Cir. 1959) (applying Oklahoma law). 
A more questionable decision involves some shotgun shells. ${ }^{174}$ The defendant had made shells of unusual explosive force, intended only for use by arms manufacturers for testing purposes. The plaintiff received a box of the shells from a friend, who in turn had received them from an unidentified third person. They looked like ordinary commercial shells except that the words "ProofLoad" and "7.5 Tons Pressure" appeared on them and on the boxes. The plaintiff did not realize the meaning of these words, and when he used one of the shells his gun barrel was blown out and he lost three fingers. A verdict for the plaintiff was set aside on the ground that there was no evidence that "the shells were put to a use to which the defendant had reason to expect that they would be put." Perhaps here too the jury properly could have found that unless the shells were more clearly marked, they might fall into the hands of someone who would be likely to use this ordinary looking ammunition in a shotgun.

A stronger case for unusual use can be made out where a youngster of five splashes inflammable fingernail polish over his clothes and then sets fire to himself, ${ }^{175}$ or where a child of nineteen months drinks poisonous shoe cleaner with fatal results, ${ }^{176}$ but it would seem that even in these cases it should not have been ruled as a matter of law that the abnormal use was unforeseeable. A jury perhaps could find, without being unreasonable, that such uses by small children could be anticipated when the product is not labelled as inflammable or poisonous so that-like matches or medicines-it will be kept out of reach. A sounder approach is illustrated by a decision allowing the jury to determine whether it was foreseeable that a small child might reach and handle the exposed parts of a washing machine. ${ }^{\mathbf{1 7 7}}$ As stated in a standard treatise, whenever the foreseeability of the abnormal use is doubtful, "it will be a question for the jury whether the maker should have anticipated it."178

In a number of cases the plaintiff has been using the product for the purpose intended, but not in the manner intended. Sometimes in such a case the defense of contributory negligence is available. ${ }^{179}$ In other cases, where no contributory negligence is found, or where the injured party is not the careless user himself, the question arises as to whether the manufacturer has created an unreasonable danger. The answer ordinarily turns on whether or not the dangerous handling of the product was foreseeable. ${ }^{180}$

The foreseeability of the dangerous handling, like that of an unusual use, would seem ordinarily to be a question for the jury. Often, however, the courts

174. Harper v. Remington Arms Co., 156 Misc. 53, 280 N.Y. Supp. 862 (Sup. Ct. 1935), aff'd, 248 App. Div. 713, 290 N.Y. Supp. 130 (1936).

175. Lawson v. Benjamin Ansehl Co., 180 S.W.2d 751 (Mo. App. 1944).

176. Boyd v. Frenchee Chem. Corp., 37 F. Supp. 306 (E.D.N.Y. 1941).

177. Dewar v. Sears, Roebuck \& Co., 49 N.Y.S.2d 654 (Sup. Ct. 1944).

178. 2 HARPER \& J AMES $\$ 28.6$.

179. See text accompanying notes $249-63$ infra.

180. See Restatement, Torts $\$ 447$ (1934); cf. 1 Frumer \& Friedran $\$ 11.04$ [1] (1960). A recent case following this view is Boeing Airplane Co. v. Brown, 291 F.2d 310 (9th Cir. 1961) (applying California law). 
have been inclined to direct a verdict for the defendant on the ground that the plaintiff's improper handling of the product definitely could not have been anticipated. This approach is illustrated in Katz v. Arundel-Brooks Concrete Corp., ${ }^{181}$ involving ready-mixed concrete containing lime. The plaintiff had purchased the product to cement his basement, and it was delivered into the cellar through a chute. The ceiling was low, so the plaintiff worked on his hands and knees. He wore ordinary work trousers which became thoroughly saturated. When the task was completed, after about five hours, he found that he had sustained third degree burns from contact with the alkali in the cement. The court directed a verdict for the defendant, partly because the caustic properties of lime products are well known, but also because of the way the plaintiff had knelt on the cement, stating that the concrete was perfectly safe where normal precautions are taken against prolonged application to sensitive portions of the skin. As the opinion itself points out, however, this product ordinarily is supplied to builders quite familiar with its qualities. It may be that when it is sold to casual users, less accustomed to working with it, a jury properly could find the product dangerous in the absence of directions for use or warnings. ${ }^{182}$

Exception may be taken to a decision involving a housewife who splashed some fluid into her eye and received permanent injury while cleaning her sink with the defendant's product. The court there also found as a matter of law that there could be no recovery, partly because "the cleaning preparation was not intended for use in the eye."183 This decision may be contrasted with the more recent one in Haberly $v$. Reardon Co., ${ }^{184}$ involving paint containing lime, called Bondex. While a boy was helping his father paint a brick wall, the father's paint brush, dripping with the paint, came into contact with the boy's eye. Within seven minutes the boy was on the operating table, but he nevertheless lost the use of his eye. The court found no difficulty in upholding a verdict for the plaintiff. When pressed with the cleaning fluid case, the court stated that this decision was "wrong." 185 It proceeded to hold that a jury "reasonably could have found that the defendant, as the manufacturer of

181. 220 Md. 200, 151 A.2d 731 (1959) ; cf. Frank v. Crescent Truck Co., 244 F.2d 101 (3d Cir. 1957) (applying New Jersey law). There the operator of a fork-lift industrial truck failed to keep his foot on a platform claimed to be too narrow, and it was crushed against a wall; the court found an unusual use and lack of proximate cause.

182. In Simmons v. Rhodes \& Jamieson, Ltd., 46 Cal. 2d 190, 293 P.2d 26 (1956), and Dalton v. Pioneer Sand \& Gravel Co., 37 Wash. 2d 946, 227 P.2d 173 (1951), both involving concrete burns, the refusal of the court to let the case go to the jury was supported by the fact that the injured persons were experienced concrete workers and were familiar with the caustic qualities of the product. In Imperial v. Central Concrete, Inc., 1 App. Div. 2d 671, 146 N.Y.S.2d 307 (1955), aff'd, 2 N.Y.2d 939, 162 N.Y.S.2d 35, 142 N.E.2d 209 (1957), which like the Dalton case involved an action against the retailer, the court considered, as in the Katz case, that wet cement was not a dangerous substance.

183. Sawyer v. Pine Oil Sales Co., 155 F.2d 855, 856 (5th Cir. 1946) (applying Louisiana law).

184. 319 S.W.2d 859 (Mo. 1958).

185. Id. at 867 . 
Bondex for use by householders, reasonably could have anticipated that it was likely that Bondex would get into the eyes of some of those users, of some of those who would be helping users, and of some of those who would be in the vicinity at the time the Bondex was being used." ${ }^{186}$ While it may be conceded that neither paint nor cleaning fluid is "intended for use in the eye," it seems quite foreseeable that such materials may in one way or another be splashed in someone's eye. If it is necessary to use components gravely injurious to the eyes, clearly this should not be done without a clear and emphatic warning. ${ }^{187}$

A recent case involved a meat grinder which was designed with a guard fastened by removable bolts and pins. A fellow employee of the plaintiff had removed the guard. While the plaintiff was feeding the unguarded machine, his foot slipped and his arm was drawn into the grinder. The court allowed a verdict against the manufacturer to stand, on the ground that the use of the machine without a guard was not so unforeseeable as "to relieve the manufacturer of liability for its failure to adopt a safe design."188 The case seems close to the line on the foreseeability issue and perhaps would have gone the other way if the machine had possessed either of two commonly employed safety devices: a mechanical method of feeding the grinding device or a permanently attached narrow neck to the cylinder enclosing the device.

In a case already considered, ${ }^{189}$ where the employee in a beauty shop dropped a one-gallon glass bottle containing highly inflammable or explosive fingernail polish, the refusal to let the case go to the jury operated against the manufacturer. There the court divided as to whether the intervening act of the careless employee who dropped the bottle saved the supplier from liability to another employee who was injured. The dissenting judges felt that since the product was supplied for handling by skilled employees, there was no reason to anticipate that it would not be handled with the highest degree of care, and that the careless act of the employee was "an independent efficient intervening cause" of the plaintiff's injury. ${ }^{190}$ The majority of the court, however, found as a matter of law that the "intervening cause might reasonably have been anticipated" by the defendant. ${ }^{191}$ It would seem that in view of the sharp

186. Id. at 863 .

187. In another area it also seems foreseeable that a farmer will reach across an exposed universal joint to control the power, even though he could have moved to a place where he could reach the lever more safely and easily; but there also the court directed a verdict for the defendant, partly because it decided the machine was being used "in a most unusual and awkward manner." Stevens v. Allis-Chalmers Mfg. Co., 151 Kan. 638, 646, 100 P.2d 723, 728 (1940), discussed at text accompanying note 93 supra. On the other hand, it is understandable how a court may rule as a matter of law that it is not foreseeable that the user of a corn dryer designed for operation at 200 degrees will turn it up to over 400 degrees and thereby cause a fire. Despatch Oven Co. v. Rauenhorst, 229 Minn. 436, 40 N.W.2d 73 (1949).

188. Smith v. Hobart Mfg. Co., 185 F. Supp. 751, 753 (E.D. Pa. 1960) ; 194 F. Supp. 530 (E.D. Pa. 1961).

189. Steele v. Rapp, 183 Kan. 371, 327 P.2d 1053 (1958), discussed at text accompanying note 57 supra.

190. Id. at 390, 327 P.2d at 1068 (Schroeder, J., dissenting).

191. Id. at 386, 327 P.2d at 1065. 
division of opinion on the court itself as to the foreseeability of the intervening act, this issue of fact here also should have been left for the jury, since a finding either way would not have been clearly unreasonable. ${ }^{192}$

A court did leave the foreseeability of intervening careless conduct to the jury in a case involving improper installation of a milk cooler. ${ }^{193}$ It was there asserted that the defendant had designed the cooler without adequate insulation, with the result that the plaintiff's decedent was electrocuted when his hand became caught between the top and the lid, after a short circuit arose on account of contact between a wire and a soldering lug. The defendant claimed that the danger arose only when the person installing the cooler failed to provide a ground, and produced evidence that this was "the proper method of installation." Since, however, the equipment was usable without a ground wire, the court held it was "for the jury to determine whether it was negligent to manufacture the appliance in this manner and design," and if the construction was hazardous, the subsequent failure to use the customary ground wire in making installation would not place the result outside of the risk created by the defendant. 194

A similar approach was adopted in a case involving a tractor equipped with a rotating pulley for use in farming operations. When the tractor went at the recommended low gear speed of 2.3 miles per hour, the pulley would rotate at 933 revolutions per minute. When the plaintiff went down hill with the tractor in low gear, at a speed from five to seven miles per hour, the rotating speed of the pulley would increase to more than 2,000 revolutions per minute. At about this speed the pulley disintegrated and injured the plaintiff. It was conceded by the manufacturer to be good practice to use the compression of the engine for braking power in going down hill, and there was no warning of the danger involved from the increased speed of the tractor. Under these circumstances the court held that "whether the speed involved here was such as should reasonably have been anticipated by defendant in designing and manufacturing the tractor ... [was a question] which should have been submitted to the jury." 195

192. See Prosser, Torts $§ 50$ (2d ed. 1955).

193. Steele v. Westinghouse Elec. Corp., 107 Ohio App. 379, 159 N.E.2d 469 (1958).

194. Likewise in a case involving a failure to inspect, the court allowed the foreseeability of this failure to go to the jury. Rosebrock v. General Elec. Co., 236 N.Y. 227, 140 N.E. 571 (1923). The defendant there had shipped a transformer to a power company with the coils toward the bottom of the transformer supported by some concealed wooden blocks. It was conceded that unless these blocks were moved before the power was turned on there was likelihood of an explosive short circuit. An explosion in fact occurred, resulting in the death of several persons. The defendant contended that even if no warning was given, the purchaser should have discovered the blocks, "by making a reasonable inspection." The court held, however, that since the use of the wooden blocks was a limited rather than a general practice in the electrical trade, a jury could find that the product was inherently dangerous.

195. Lovejoy v. Minneapolis-Moline Power Implement Co., 248 Minn. 319, 326, 79 N.W.2d 688, 693 (1956). In another case involving careless use, some volunteer workers 
It thus appears that while some courts are inclined to direct a verdict for the defendant where they consider that the product was used in a careless manner, others, more in accordance with accepted tort principles, will leave the foreseeability of the intervening careless handling to the jury, particularly where a serious danger arises if there is any improper handling of the product.

Foreseeability of harm from fire. A number of recent cases have involved products which cause grave harm when they catch fire. These decisions have gone considerably beyond those involving specifically inflammable substances, such as gasoline, which were recognized as inherently dangerous by courts and legislatures even before the adoption of the modern MacPherson rule. ${ }^{196}$ More recently, the statutes have been extended to such matters as inflammable fabrics and other hazardous substances. So the Federal Flammable Fabrics Act, effective since 1953, provides penalties for the manufacture, sale or transportation in interstate commerce of wearing apparel which is so highly inflammable as to be dangerous when worn. ${ }^{197}$ Various other inflammable substances are covered by the recently enacted Federal Hazardous Substances Labeling Act. ${ }^{198}$ While these Acts are penal in nature, they greatly facilitate proof in civil actions. Violation of such statutes is negligence per se, or at least evidence of negligence, and conversely, compliance with the Act is at least some evidence of the exercise of due care. ${ }^{199}$

Many of the cases involving inflammable products have primarily involved breaches of a duty to warn, but in others the real difficulty, as indicated in the discussion of the inflammable dress cases, ${ }^{200}$ is that the composition or design of the product is unreasonably dangerous, with the result that a warning might not be sufficient to make the product safe. A case which illustrates this is Hentschel $v$. Baby Bathinette Corp. ${ }^{201}$ where one of the defendants had manufactured, and the other had sold, a baby bathinette with supports made of an alloy composed almost entirely of magnesium. When subjected to a temperature of around 1100 degrees Fahrenheit the thin sheets of which these supports were made would burn fiercely, and it was extremely difficult to extinguish any fire with water since, unless the fire were smothered, water would

in a church attempted to start a gas burner by removing a plug which was needed for some models but was a useless appendage on this one. Removal of the plug allowed gas to escape into the combustion chamber, causing an explosion which killed the plaintiff's decendent. There was no clear warning concerning the plug, and under these circumstances the court allowed the jury to determine "whether defendant reasonably should have anticipated that inexperienced operators" would follow the course here taken. If so, there was negligence either in failing to warn or to provide safety features which would have made more difficult the removal of this functionless plug. Hartmon v. National Heater Co., 240 Minn. 264, 273, 60 N.W.2d 804, 811 (1953).

196. 2 FRUMER \& FRIEDMAN $\$ 35$.

197. 15 U.S.C. $\$ \S 1191-1200$ (1958).

198. 15 U.S.C. $\$ \$ 1261-73$ (Supp. II, 1959-60).

199. See 1 Frumer \& FrIEDMAN $\$ 8.07[1]$.

200. See text accompanying note 112 supra.

201. 215 F.2d 102 (2d Cir. 1954) (court sitting in New York applying Michigan law), cert. denied, 349 U.S. 923 (1955). 
cause the release of inflammable hydrogen. While the bathinette was in the bathroom of an apartment, a fire of unexplained origin started there and reached the bathinette. As a result the fire could not be extinguished until the alloy was almost consumed. The plaintiffs were able to get their children out of the apartment but were injured in so doing. The wife received part of her burns when one of the bluish flames from the bathinette shot across the hall into her bedroom. The trial judge instructed the jury to find for the defendant if the bathinette was not the cause of the original fire but "became subjected to flames from a previously started fire."202 The court of appeals upheld this instruction, stating that "where an article is not inherently dangerous in its normal or intended use neither its manufacturer nor vendor is liable for a result which is brought about by its subjection to unusual and extraordinary conditions." 203

- A scholarly dissenting opinion by Judge Frank takes the position that the ordinary intended use of the bathinette was in a dwelling; that the product was unreasonably dangerous since the "defendants knew (or should have known) that the presence of the bathinette would easily transform an ordinary house or apartment into a fire-trap."204 Since there are about a million household fires a year in the country, Judge Frank thought that the intervening fire could not be regarded as extraordinary or unforeseeable. It was suggested that if the prevailing opinion is generally applied, a manufacturer could supply with impunity a wall paint which would release poisonous fumes in the event of a fire, or window strips made of material of explosive inflammability. It is further suggested in the dissenting opinion that a warning should have been attached to the bathinette, but the writer concedes in this connection:

To comprehend the nature of defendants' negligence, one has but to ask whether defendant could have sold their bathinettes, if there had been affixed an easily-readable notice saying, "If a fire happens in your home, this bathinette will probably increase the dangers greatly, because the magnesium may ignite, causing unusual spurts of flame which will be peculiarly difficult to extinguish." 205

As the above quotation suggests, an adequate warning probably would preclude the sale of the product. The real difficulty seems to lie in the material chosen for its construction. If some other material could have been used without substantially increasing the expense or impairing the efficiency of the product, it would seem that a jury could find that an unreasonable danger was created, even though a household fire may be, as the prevailing opinion states "unusual and extraordinary," for it is conceded by the majority that danger from a fire to the plaintiffs and their children was greatly increased by the presence of the magnesium.

202. 215 F.2d at 104.

203. Id. at 105 .

204. Id. at 111 .

205. Ibid. 
When we turn from things that are apt to be ignited simply from a dropped match or a carelessly handled cigarette, as distinguished from a conflagration, liability is much more apt to be conceded. This is shown by recoveries in the inflammable dress cases, ${ }^{206}$ although it should be observed that where a garment does not contain some highly inflammable chemical, such as nitro-cellulose which will cause a sudden or flash fire, but is simply made of combustible cloth the court may rule that the danger is not unreasonable. ${ }^{207}$ Perhaps the case which goes furthest in allowing recovery in this situation is Martin $v$. Bengue, Inc. ${ }^{208}$ There the plaintiff, at home with a heavy cold, had an ointment, Ben-Gay, rubbed on his chest, shoulders and neck twice a day for several days, all in accordance with directions. As contemplated by the manufacturer, vapors emitted by the ointment were confined between the plaintiff's pajama top and his body. When the plaintiff, attempting to light his cigarette, struck a match, its head fell off and set fire to his pajama top. He was unable to put the fire out, according to the testimony of his expert witness, because the confined vapors ignited and caused a flash fire, with the result that he soon was enveloped in flames.

The trial court dismissed the action, and the intermediate appellate court affirmed on the ground that the chance of this accident was so remote that a manufacturer of ordinary prudence would have disregarded it. The Supreme Court reversed, holding that a jury properly could find an unreasonable danger. After noting that there are between fifty-five and sixty million smokers in this country, the court concluded that "the danger of igniting the confined vapors, by a match, cigarette, or otherwise, cannot fairly be said to have been so patently remote as to justify the court's withdrawal from the jury of its normal function of passing on the issue of foreseeability."209 Here again the court emphasized the absence of a warning. If there were substantial reasons for using components which produced the vapors, it would seem that an adequate warning should protect the manufacturer in this situation. On the other hand where a manufacturer makes easily inflammable pyroxoloid combs for use in a beauty parlor, where it is customary to use heat which would be sufficient to ignite the combs in drying hair, it would seem that a warning to the beauty parlor operator of the fire risk would not be sufficient to save the manufacturer from liability. Combs of such composition create an unreasonable danger whenever they are furnished for use in such a place. ${ }^{210}$

206. See text accompanying note 112 supra.

207. Dempsey v. Virginia Dare Stores, Inc., 239 Mo. App. 355, 186 S.W.2d 217 (1945).

208. 25 N.J. 359,136 A.2d 626 (1957).

209. Id. at 372, 136 A.2d at 633 .

210. Farley v. Edward E. Tower \& Co., 271 Mass. 230, 171 N.E. 639 (1930). There is a case somewhat similar to Martin v. Bengue, Inc., involving an oil shampoo with a flashpoint of 171 degrees Fahrenheit. While the plaintiff was using this product she struck a match to light a cigarette, and thereupon a flash of flame engulfed her hair. The jury found for the plaintiff, but the verdict was set aside on appeal, partly because no one expressly contradicted the testimony of the defendant's expert, who when asked if it would have been possible under the situation stated for the shampoo to have ignited and caused 
Foreseeability of allergic reactions. It has been shown that a manufacturer is not under a duty to anticipate abnormal uses of his product. In the past, the courts have felt the same way about abnormal users, and have held that a manufacturer is under no duty to take steps to protect those who are sensitive or allergic to some ingredient in his product which does not threaten harm to most people. So in one of the earlier cases the court stated, "We think the jury should have been told in appropriate language that, if they believe the proximate cause of the injuries to appellee was his abnormal hypersensitiveness, but for which the injury would not have occurred, a verdict should be returned for defendant."211 A considerably later case likewise takes the position that there must be "reasonable foreseeability of danger and harm to the normal person contemplated by the law."212 In recent years, however, the courts have imposed a duty toward allergic users in an increasing number of cases. ${ }^{213} \mathrm{Or}$ dinarily this duty is fulfilled by a warning or by instructions for making of tests. $^{214}$ It would seem, however, that where a substantial number of people are likely to suffer allergic reactions of a serious character from an ingredient in a product, there might be a duty to eliminate, where feasible, the offending ingredient.

In a number of cases the manufacturer has escaped liability on grounds of his lack of knowledge that the product would cause an allergic reaction. ${ }^{215}$ Recent decisions, however, emphasize that in the area of allergic reactions, as in other fields, the manufacturer is held to the knowledge and skill of an expert. ${ }^{210}$ It would seem that if the foreseeable allergic reaction is either slight or extremely rare a manufacturer would not have created any unreasonable danger, since there would be so little likelihood that any substantial harm would occur. It is clear, however, that a manufacturer must take into consideration an increasingly small percentage of allergic users. While as late as 1951 a court emphasized as a basis for directing a verdict for the defendant that the permanent-wave lotion there involved produced a reaction "in but one allergic woman in 1,000 using it,"217 a leading decision a few years later found a duty to warn where a much smaller percentage of allergic users was in-

the fire, replied, "It would not have been possible for it to happen." Apparently the court felt that there was no evidence that the product was dangerous unless the plaintiff practically touched her hair with the match. Olds v. Wood, 196 Va. 960, 86 S.E.2d 32 (1955).

211. Hamilton v. Harris, 204 S.W. 450, 451 (Tex. Civ. App. 1918).

212. Bennett v. Pilot Prods. Co., 120 Utah 474, 478, 235 P.2d 525, 527 (1951), involving a suit against a distributor.

213. See Noel, The Duty to Warn Allergic Users of Products, 12 VAND. L. REv. 331 (1959).

214. 2 HARPER \& JAMES $\S \S 28.7$ to -.8 .

215. Briggs v. National Indus., Inc., 92 Cal. App. 2d 542, 207 P.2d 110 (1949); Gould v. Slater Woolen Co., 147 Mass. 315, 17 N.E. 531 (1888). See also Bennett v. Pilot Prods. Co., 120 Utah 474, 235 P.2d 525 (1951) (suit against distributor).

216. Wright v. Carter Prods., Inc., 244 F.2d 53 (2d Cir. 1957) (applying New York law); Braun v. Roux Distrib. Co., 312 S.W.2d 758 (Mo. 1958).

217. Bennett v. Pilot Prods. Co., 120 Utah 474, 476, 235 P.2d 525, 526 (1951). 
volved. ${ }^{218}$ In that case, involving a deodorant, the manufacturer had received 373 complaints during the three year period in which the plaintiff had been using the product, but it appeared that over the same period the defendant had sold over 82 million jars of the deodorant. In holding that a duty to warn might arise even though only a "miniscule" percentage of potential users were endangered the court emphasized that "duties to warn are not, in all cases, measured by solely quantitative standards" and found that the statistical analysis of injury, "so heavily relied upon by the trial court," was only one relevant factor on the issue of foreseeability. ${ }^{219}$

Where no prior allergic injuries at all of the type suffered by the plaintiff have occurred, it would seem that the manufacturer should not incur any liability on negligence principles. In a recent hair dye case, ${ }^{220}$ however, a duty to warn against the systemic allergic reaction there suffered by the plaintiff was imposed on the manufacturer even though over fifty million packages of the hair dye had been distributed, and it was conceded by the plaintiff that "unless the present case is an instance, there has never been either a reported or an established case of periarteritis nodosa caused by paraphenylenediamine hair dye." 221 'In spite of the fact that no previous injury of this sort had occurred, the court sustained a finding by the jury that the defendant "knew, or by the exercise of due care should have known" of the risk of systemic injury, and should have given a warning of this type of harm along with the warning actually given of the more common allergic reactions. In substance the court seems to be imposing a liability without fault on the manufacturer, and it is doubtful if a finding of negligence would be sustained under these circumstances in other jurisdictions.

\section{Causation and Result Within the Risk}

After the plaintiff has established that, under the standard of unreasonable danger, the design of a product involves a likelihood of harm which should have been foreseen by the manufacturer, he still must show that his injury resulted from the dangerous design of the product. ${ }^{222}$ The hurdle of causation, however, is less formidable in design cases than in cases involving defects in the manufacture of an individual item. In the latter cases there is always a possibility that the defect arose after the product left the manufacturer's hands; if there is negligence of design it is apparent that the danger was not created by any subsequent handling of the product or by its wearing out with the lapse of time. ${ }^{23}$ Nonetheless even in design cases the matter of proving law).

218. Wright v. Carter Prods., Inc., 244 F.2d 53 (2d Cir. 1957) (applying New York

219. Id. at 56 .

220. Braun v. Roux Distrib. Co., 312 S.W.2d 758 (Mo. 1958).

221. Id. at 761 .

222. 2 HARPER \& JAMES $\S 28.12$.

223. Thus in the case of the exploding Anglia car, note 32 supra and accompanying text, it was not established that the small leak in the gas tank existed at the time the auto- 
cause in fact remains; it must be shown that the accident happened on account of the unsafe design. Even where there is causation in fact, the defendant still may escape liability on the ground that the result is not within the risk, that the accident in question was not one of the general sort to be anticipated as a result of the design in question. Finally, assuming that an unreasonable risk has been created with reference to the type of accident that occurs, the risk may have been terminated by adequate notice or by discovery of the danger. While these problems have been touched upon in the preceding analyses, it seems appropriate to treat them separately.

\section{Callse in Fact}

In a good many of the cases considered earlier where the accident results from abnormal or careless use of the product, ${ }^{224}$ the decision may be based on the absence of causation in fact so that the manufacturer escapes liability, even though there may have been carelessness of design, because the harm resulted from the improper use. There are a few design cases more specifically based on the causation point. Thus in Ellis v. H.S. Finke, Inc., ${ }^{225}$ where a hoist lacked a safety device which may have been essential to make it safe, a verdict was directed for the defendant because there was no evidence that the safety device would have prevented this particular fall of the hoist. Likewise in a case where a vessel or tower used in refining oil may have been unsafe because it lacked a side exit, one reason for directing a verdict for the defendant was lack of evidence that the plaintiff's decedent, who was asphyxiated inside the tower by carbon monoxide gas, "would have been spared had the vessel provided escape through side manways." 226

Decisions such as these simply illustrate how in a design case, as in other areas of tort law, the plaintiff must establish that the harm which he suffered resulted in fact from the defendant's negligence. Sometimes this may be established by circumstantial evidence, as in the case of the vaporizer which lacked a needed automatic device to cut off the current when the fluid evaporated. ${ }^{227}$ The court there found that evidence as to the melted condition of the vaporizer, and the ignited state of the chair on which it was placed, was sufficient to establish that the improperly designed product started the fire. In other cases causation in fact is established by expert testimony. ${ }^{228}$ It may be estab-

mobile left the manufacturer's hands, but the plaintiffs nevertheless proved causation by showing negligence of design in failing to provide vents for escaped gasoline or vapor where the tank was located in the trunk.

224. See text accompanying notes 164-95 supra.

225. 278 F.2d 54 (6th Cir. 1960) (applying Tennessee law), discussed at text accompanying note 44 supra.

226. Marker v. Universal Oil Prods. Co., 250 F.2d 603, 606 (10th Cir. 1957) (applying Oklahoma law).

227. Lindroth v. Walgreen Co., 407 Ill. 121, 94 N.E.2d 847 (1950), discussed at text accompanying note 30 supra.

228. See 1 Frumar \& Friedman \& 12.02[2]. 
lished also by evidence of prior accidents involving an article of similar design or composition. ${ }^{229}$

\section{Proximate Canse or Result Within the Risk}

Even where an unsafe design and cause in fact have been established, the defendant may escape liability because the harm incurred is not of the kind to be anticipated from the improper design. This does not mean that the exact nature of the accident must be anticipated. As in other areas of tort law, it is not necessary that the defendant, "should have been able to anticipate the particular chain of events that would result in injury in order to be held liable."230 It is necessary, however, that the general type of hazard be foreseeable. ${ }^{231}$

This point was the crucial one in Hatch v. Ford Motor Co., ${ }^{232}$ where the defendant had designed one of its models with a pointed radiator ornament which projected beyond the front of the radiator grill. While the car was parked on a road, a child of six proceeding along the road collided with it and the ornament pierced his eyeball, with resulting loss of the eye. A statute prohibited the sale or operation of a motor vehicle equipped with a radiator ornament which extended beyond the grill. Plaintiff alleged negligence per se based on violation of this statute, and common law negligence based on unsafe design, creating a risk that the body of a person coming into contact with the front portion of the vehicle would be pierced. The defendant's demurrer was sustained. With reference to the intent of the statute the court stated:

It was not designed to protect those who, solely by reason of their own act or omission, might come in contact with it as an inert object lawfully standing unattended upon a highway .

....

In our opinion the persons whom the statute was designed to protect are those against whom the vehicle might be brought in contact through its being driven upon a highway and the hazard which the statute was designed to alleviate was the hazard created by the pointed ornament when the car was in movement thus rendering the ornament capable through its own motion of piercing the anatomy of a person with whom the car collided. ${ }^{233}$

Perhaps this is a correct interpretation of the risk intended to be guarded against, although it seems especially likely that the legislature intended to guard against any sort of collision with this unnecessary protruding ornament,

229. Gall v. Union Ice Co., 108 Cal. App. 2d 303, 239 P.2d 48 (1951). Cf. Prashker v. Beech Aircraft Corp., 258 F.2d 602 (3d Cir.), cert. denied, 358 U.S. 910 (1958) (applying Delaware law), discussed at text accompanying notes 81-82 supra.

230. Katz v. Swift \& Co., 276 F.2d 905, 906 (2d Cir. 1960) (applying New York law), discussed at note 28 supra.

231. 2 HARPER \& JaMIES $§ 18.2$; see also Frank, J., dissenting, in Hentschel v. Baby Bathinette Corp., 215 F.2d 102, 105 (2d Cir. 1954), cert. denied, 349 U.S. 923 (1955)

(applying New York law), discussed at text accompanying notes 201-05 sitpra.

232. 163 Cal. App. 2d 393, 329 P.2d 605 (1958).

233. Id. at 399,329 P.2d at 608 . 
as where someone falls against a parked car in the dark, or swerves into the parked vehicle to avoid some other accident.

With reference to common law negligence of design, the court found that there was no negligence in failing to make a vehicle with which a person might collide while the vehicle was in a standing position, and indicated a noticeable reluctance to let the triers of fact "be the arbiters of the design of automobiles." Perhaps the court again is taking too restricted a view of the risk involved from an ornament of this type. ${ }^{234}$ It is clear, however, that whenever a court concludes that the particular accident is not one of the foreseeable risks from a particular unsafe design, the manufacturer will not incur responsibility. This result may be expressed by saying that there is no proximate causation, or, more understandably, by finding that there was no negligence with reference to the accident that occurred. ${ }^{235}$

\section{Termination of Risk Created by a Manufacturer}

There are a number of cases where the plaintiff establishes that a dangerous design was used, with respect to the type of harm involved, but it is asserted that by the time of the accident the risk originally created by the manufacturer has terminated. The circumstance ordinarily urged as effecting termination of the risk is that the purchaser of the product has been warned of the danger, or has otherwise discovered it. Because of this knowledge recovery often is denied not only to the informed purchaser himself, who may be guilty of contributory fault, but also to third persons who are not informed of the danger, usually on the ground that the use of the product by the informed purchaser is a "superseding cause" which insulates the manufacturer's negligence.

The two decisions which best illustrate this matter in the design field are Ford Motor Co. v. Wagoner, ${ }^{236}$ and Comstock v. General Motors Corp. ${ }^{237}$ In the Ford case the defendant manufactured a certain model car with a hood catch so designed that it tended to come loose when the car was subjected to a severe jolt, so that the hood might fly up and obscure the driver's vision. When this danger was discovered, the manufacturer at once provided all its dealers with an auxiliary catch, with instructions to install it on all cars of this model without charge. Norman, the owner of one of the cars, was tendered one of the catches but declined it, since he had traveled about 10,000 miles in the car, and had not experienced any trouble with the hood: While the car was being driven by a purchaser from Norman, the hood flew up, the vehicle left the road as a result, and the plaintiff, a guest in the car, was injured.

234. In that connection, in a case involving a projecting open rear window of a parked station wagon, the court thought a jury could reasonably find that injury to a pedestrian who collided with the window was foreseeable. The accident there occurred at night, while the plaintiff was crossing the street a short distance from the prescribed cross-walk. Schaublin v. Leber, 50 N.J. Super. 506, 142 A.2d 910 (1958).

235. 2 Harper \& Jamies $\$ 18.2$; Seavey, Cogitations on Torts 34 (1954).

236. 183 Tenn. 392, 192 S.W.2d 840 (1946).

237. 358 Mich. 163,99 N.W.2d 627 (1959). 
The Tennessee Supreme Court sustained a directed verdict for the defendant on the ground that the intervening conduct of Norman destroyed the causal connection between the defendant's negligence, which was assumed, and the accident. The opinion emphasizes that since Norman was an automobile salesman there was no room for "any reasonable deduction other than that he was consciously on notice of the defect and knowingly rejected the offered remedy."238 Since this conscious consent to the risk would bar recovery by Norman himself, the court thought that it likewise destroyed the causal connection between the defendant's negligence and the injury to the plaintiff.

While Norman's consciousness of the facts clearly is of significance, it may be that the court over-emphasized this factor. It is conceded in the opinion that "the intervening act of even an independent conscious agency will not exculpate the original wrongdoer ... unless . . . the negligent intervening act ... could not have been reasonably anticipated."239 On that vital point the court merely states, "Certainly, Ford Company could not have anticipated the conduct of Norman in rejecting the safety catch." At least two commentators have felt that the intervening negligence of Norman was in fact foreseeable. ${ }^{240}$ In view of this division of opinion, perhaps a jury could have found that Norman's conduct was foreseeable without being manifestly unreasonable. The fact that voluntary assumption of risk would, as the court points out, bar a suit by Norman does not in itself mean that this would bar a suit by the plaintiff, since the defense of assumption of risk is personal to Norman. The fact that the manufacturer took considerable precautions to avoid the consequences of earlier negligence, which were frustrated by the improper conduct of Norman, may tend to support the decision; but as a general proposition, subsequent careful conduct does not relieve a defendant of the consequences of earlier negligence, where the harm nevertheless results, so long as the defendant's prior negligence is a substantial factor in bringing it about. ${ }^{241}$

The Wagoner decision, whether sound or not, illustrates a general tendency to hold that where the manufacturer can show that an intervening actor has consciously assumed the risk of using the dangerous product, the case should be taken from the jury. ${ }^{242}$ The case does not hold, however, that mere negli-

238. 183 Tenn. at 404,192 S.W.2d at 845.

239. Id. at 399, 192 S.W.2d at 843. See also 2 Restatenent, Torts $\$ 447$ (1934).

240. See Millèr, Liability of a Mannfacturer for Harm Done by a Product, 3 Srracuse L. Rev. 106, 113 (1951) ; Note, 13 U. CHr. L. Rev. 518, 521 (1946). Cf. Noe1, Products Liability of a Mamufacturer in Temessee, 22 TENN. L. REv. 985, 991-93 (1953).

241. 2 Restatement, Torts $\$ 437$ (1934); 2 Harper \& James $\$ 28.7$, stating that the Wagoner case disregards generally recognized principles on this point, and observing that where the original flaw represents "an unreasonable and avoidable danger, later steps to avoid injury, however reasonable, should not shield the maker from liability for his negligence."

242. Prosser, Torss $\$ 84$, at 504 (2d ed. 1955). In Olds Motor Works v. Shaffer, 145 Ky. 616, 621, 140 S.W. 1047, 1049 (1911), the court says that "the maker will not be liable, if it is made to appear that the purchaser had knowledge of the defects . . before the third party was injured in using it." The case of E.I. du Pont de Nemours \& Co. v. Ladner, 221 
gence on the part of the third party, as distinguished from conscious assumption of risk, always will be regarded as unforeseeable and as relieving the manufacturer from liability.

In the other leading case on termination of risk, Comstock v. General Motors Corp.,${ }^{243}$ the court shows much less inclination to find that intervening discovery of the hazard will protect the manufacturer of a negligently designed product. The 1953 Roadmaster Buick there involved was designed with power brakes which occasionally gave way completely. This occurred because a ring sealer in the master brake cylinder tended to change slightly in dimensions when exposed to cold temperatures and brake fluid pressures, allowing the fluid to escape. When this danger was discovered the unit was redesigned, and the manufacturer made available to dealers a kit for the replacement of the defectively designed unit, which was to be replaced at the manufacturer's expense. No effort was made to notify the owners of defective cars. The representative of the manufacturer testified that any notification was the dealer's responsibility, and the dealer testified that the manufacturer's service department told him not to send letters, since the information would then become public.

One of the owners, Friend, discovered that his brakes were not operative. He called a repairman at the dealer's garage, Wentworth, who said that he knew what was wrong and to bring the car in. Using the emergency brake, with his wife's car ahead as a bumper, Friend carefully drove his Buick into the garage and left it with Wentworth, who omitted to place the usual "no brake" sign on the car. A few minutes later Wentworth, completely forgetting that the car had no brakes, drove it toward a repair stall. When the brakes failed to function, the leg of an employee working at the rear of another vehicle was crushed.

In a suit against the manufacturer it was urged that assuming there was negligence of design, or in any event an improper failure to warn the owners of this model after the inadequate design was discovered, there could be no recovery in this case because the owner of the car became completely informed of the brake failure, with the result that there was no cause in fact. The court replied that Friend evidently took good care of his automobile and that a prompt warning to him "would in all likelihood have meant repair before any brake failure occurred." The manufacturer then urged that Wentworth's negligence was an intervening or superseding cause. The court held, however,

Miss. 378, 73 So. 2d 249 (1954), involving a chemical furnished by the defendant for use in animal food, holds that a warning to the distributor that the chemical supplied is dangerous to cattle, as distinguished from hogs and poultry, is sufficient to save the defendant from liability. While the court cites the Wagoner decision, the facts in the Ladner case seem somewhat more favorable to the defendant, since the intervening negligence was by a supposedly reliable processor of animal food, who acted against urgent written warnings from the manufacturer. See also Stultz v. Benson Lumber Co., 6 Cal. $2 \mathrm{~d} 688,59$ P.2d 100 (1936), where an unsuitable plank was supplied for scaffolding, and the contractor's informed use of the plank prevented the supplier from being liable.

243. 358 Mich. 163, 99 N.W.2d 627 (1959). 
citing the Restatement of Torts, ${ }^{244}$ and reversing the trial judge, that the intervening negligence would not protect the manufacturer, stating:

It takes no great imagination to foresee possibility of some negligence in the handling of a car on which a "no brake" condition is known to exist. This is particularly true if such "no brake" conditions are created in large numbers. The jury could have found that the negligence of General Motors set this whole train of events in motion and played a substantial role in the final event. The intervening negligence herein was not deliberate or wanton or wilful. Nor was it extraordinary in character. Wentworth did not deliberately determine to drive a car with no brakes. He forgot. No more human error can be conceived of. We think such forgetfulness as is revealed by the facts herein cannot be held to go beyond reasonable foreseeability. ${ }^{245}$

The Wagoner case was distinguished on the ground that there Norman deliberately continued to use the car with awareness of its lack of repair, but some doubt is placed on the validity of this distinction by the fact that Wentworth may have intentionally omitted to obey the precautionary rule that a "no brake" sign be placed on the car.

Perhaps the court that decided the Wagoner case, and some other courts, would consider that the risk in the Comstock case had terminated, and that this particular Buick had come to a "safe" place when it was parked in the garage with instructions to fix the completely inoperative brakes. The decision illustrates, however, that where the product manufactured is an extremely dangerous one, judges may be reluctant to relieve the manufacturer of liability even though there is intervening discovery of the hazard. In the Comstock case the court remarked that "a modern automobile equipped with brakes which fail without notice is as dangerous as a loaded gun." Precedent for the decision can be found in a rather old case where an oil company supplied to a grocer a highly dangerous mixture of kerosene and gasoline. The grocer had considerable reason to know that the company had not effectively corrected this mixture, but nevertheless sold some of the product to plaintiff's decedent, who unfortunately used it to light the morning fire in the family stove. The court there said that the defendant, in placing this dangerous mixture into the hands of a busy storekeeper "distracted by the thousand petty details which press daily upon such a man" should have realized that he might forget the danger and make a sale. ${ }^{246}$ Forgetfulness is particularly apt to occur where the person supplied with a product will suffer the disadvantage of having unsaleable goods on his hands if his memory is kept fresh. ${ }^{247}$ Perhaps the brakeless Buick was as dangerous as this explosive mixture. ${ }^{248}$

244. 2 RestateMent, ToRTs $\$ 447$ (1934).

245. 358 Mich. at $179-80,99$ N.W.2d at $635-36$.

246. Kentucky Independent Oil Co. v. Schnitzler, $208 \mathrm{Ky} .507,516,271$ S.W. 570, 574 (1925).

247. 2 Restatensent, Torts $\S 388$, comment $l$ (1934).

248. So also in Farley v. Edward E. Tower \& Co., 271 Mass. 230, 171 N.E. 639 (1930), discussed at text accompanying note 210 supra, the court found that the risk from the in- 


\section{Contributory Fault}

In some cases based on negligence of design or composition it is asserted that the plaintiff is barred by contributory negligence or voluntary assumption of risk, defenses which of course are available in negligence actions generally. If the design is reasonably safe except for the circumstance that the manufacturer has given improper directions for use, or has failed to give a needed warning, these defenses are not apt to have merit, for ordinarily it can not be shown that the plaintiff realized or should have realized the risk, or consented to it, where it is established that the design is dangerous unless accompanied by adequate directions or warnings. So unless the plaintiff was made aware of the danger from some other source, the defendant can not effectively argue that the accident was due to the contributory fault of the plaintiff in failing to realize the danger which required the warning, or the shortcomings which made the instructions inadequate. For this reason, it has been urged that in this situation the question of contributory negligence should not even be submitted to the jury. ${ }^{249}$ It is evident, however, that the courts do not explore the matter to this extent, and frequently do submit the issue of contributory fault to the jury even though the only negligence alleged relates to the duty to give proper warnings or directions. ${ }^{250}$

Where the principal negligence complained of is not a failure to warn or to give proper directions, but the use of a design which creates an unreasonable danger, it is clear that contributory negligence or voluntary assumption of risk may be appropriate issues. There is a tendency in the design cases, however, as in products cases generally, to restrict the defense of voluntary assumption of risk to cases where the plaintiff in fact realized the risk and consented to it. ${ }^{261}$ This may be illustrated by one of the few design cases in which a judgment for the plaintiff has been set aside on grounds of voluntary assumption of risk. There it had been found at the trial that a motorcycle was unsafely designed because it lacked a device to lock the knob of a "damper" intended

flammable celluloid combs there involved was not terminated when the manufacturer notified the dealer of their inflammable character. The situation seems much like that in another of the older cases where the defendant manufactured highly infiammable stove polish, and was not protected by the fact that the retailer had full knowledge of the dangerous character of the product. Clement v. Crosby \& Co., 148 Mich. 163, 111 N.W. 745 (1907).

249. See Dillard \& Hart, Product Liability: Directions for Use and the Duty to Warn, 41 VA. L. REv. 145, 163 (1955).

250. See 1 Frumer \& Friedman $\$ 8.06$, citing a number of cases which submit the contributory fault issue to the jury in duty to warn cases.

251. See, e.g., Moran v. Pittsburgh-Des Moines Steel Co., 166 F.2d 908, 919 (3d Cir.), cert. denied, 334 U.S. 846 (1948) (to assume a risk "one must know what he is assuming"). On the other hand, the court in one leading design case seems to be goirg beyond the concept of consent, either subjective or objectively manifested, in a dictum that the plaintiff "might be taken" to have assumed the risk if the danger had been sufficiently "obvious." Northwest Airlines, Inc. v. Glenn L. Martin Co., 224 F.2d 120, 124-25 (6th Cir. 1955), discussed at text accompanying note 158 supra. See generally Keeton, Voluntary Assumption of Risk in Products Liability Cases, 22 LA. L. Rev. 122, 141-43 (1961). 
to prevent the wobbling of the front wheel at high speeds. The plaintiff's own testimony showed that he continued his journey "with full knowledge and appreciation of the danger from the constantly unwinding damper and the resultant steering wobble." Under these circumstances the plaintiff was barred by voluntary assumption of risk, since he chose to continue the trip without "the slightest compulsion of business or otherwise."252

- It may be that in the current suits against cigarette manufacturers on the ground that their products are partly composed of materials which cause cancer, the defense of contributory fault will be a crucial point. Where sufficient evidence is presented to establish causation and negligence, it seems likely, in view of the great amount of publicity which has been given to this danger, that many plaintiffs would be barred by voluntary assumption of risk or contributory negligence. ${ }^{253}$ When, however, the suit is based on smoking which terminated several years ago, before all the publicity, the situation may be different. The negligence of the defendant manufacturer still may be established on the basis of this superior and specialized knowledge as an expert, which should have led to tests to discover more about the composition of this product and the presence of lurking dangers. ${ }^{254}$ The smoker, on the other hand, with no duty to know as an expert, might well be free of contributory fault even though he has used a product found to create an unreasonable danger if distributed without a warranty. 255

In a number of cases earlier considered involving abnormal or careless handling of the product, the court may speak in terms of contributory negligence or voluntary assumption of risk, when the real issue is whether there was any negligence of design. As has been shown, ${ }^{256}$ however, a manufacturer is under no duty to anticipate abnormal uses of his product. Where the product is being used in an unforeseeable way, there is no negligence, or as the courts more often say, no proximate causation with reference to the accident that occurs, and the issue of contributory fault therefore is not reached. Likewise there may be no duty to so design a product that it can be used carelessly with impunity. In that connection, however, it should be considered that often the user of the product, as in Katz v. Arundel-Brooks Concrete Corp., ${ }^{257}$ involving cement which caused burns, does not have the expert knowledge of

252. Saeter v. Harley Davidson Motor Co., 8 Cal. Rptr. 747, 752-53 (Sup. Ct. 1960).

253. See Torts-Liability of a Cigarette Mannfacturer to a Smoker Who Develops Cancer, 33 N.Y.U.L. Rev. 417 (1958).

254. Pritchard v. Liggett \& Myers Tobacco Co., 295 F.2d 292 (3d Cir. 1961). This decision remanded the case for a new trial on both the negligence and the warranty issues.

255. See Rossi, The Cigarette-Cancer Problem: Plaintiff's Choice of Theories Explored, 34 So. CAL. L. Rev. 399, 403 (1961).

256. See text accompanying notes 164-95 supra.

257. $220 \mathrm{Md}$. 200, 151 A.2d 731 (1959), discussed at text accompanying note 181 supra. See also Katz v. Swift \& Co., 276 F.2d 905 (2d Cir. 1960) (applying New York law), discussed at note 28 supra, where the plaintiff noticed that a rubber band binding the shanks of a lamb was not twisted in the usual figure eight pattern, but did not realize that as a result the band would fly off and strike him when it was grasped. 
the product possessed by the manufacturer. In other cases, involving more experienced or expert users, the specialized knowledge of the plaintiff may lead the court to find contributory negligence in the use of the product as a matter of law. ${ }^{258}$

In some cases the court may hold as a matter of law that there is no negligence of design, when in fact the main consideration is that the plaintiff has been guilty of contributory fault. This is particularly apt to be the case where a court finds that the defect in the product is obvious and not latent. As has been shown, if in fact the so-called obvious defect is one commonly avoided by other manufacturers, and its dangerous character often is not realized by users of the product, there may in fact be negligence of design. ${ }^{259}$ Where, however, a particular plaintiff is sufficiently aware or the danger as well as of the defect, he may be barred by contributory fault.

Perhaps the case which goes furthest in allowing a jury to find for the plaintiff in the face of strong indications of both abnormal use and contributory fault is Webb v. Olin Mathieson Chemical Corp. ${ }^{260}$ There the injury occurred when the central or "receiver" portion of a rifle manufactured by the defendant failed to withstand the stress of a backfiring shell. There was some evidence that the steel used in the receiver contained too much sulphur, and as a result was unduly brittle. The principal defense was that the plaintiff had made numerous alterations. He had replaced the barrel with one which would take a larger caliber cartridge and then had resized the new barrel to enlarge it a bit further, and had placed a new stock on the gun. Most significantly, his tinkering included the enlargement of the extractor slot and it was urged that this increased the danger of an explosion back into the receiver, by diminishing the support to the side of the cartridge. It further appeared that the plaintiff had reloaded his shells, and in so doing had increased the amount of powder. Under these circumstances, a sharply divided court held that the jury could find the plaintiff free from contributory negligence. The dissenters considered that the use of the reloaded shells in this much-altered product established contributory negligence as a matter of law. The decision seems close to the line both with respect to contributory negligence and abnormal use.

It should be added that ordinarily in design cases the user is not required to test products designed by experts, and even though he does make some inspection, his failure to discover the hazard does not necessarily establish contributory negligence. ${ }^{261}$ Furthermore, as in other areas of negligence law, contributory negligence may be a defense even though the manufacturer's neg-

258. Day v. Barber-Coleman Co., 10 Ill. App. 2d 494, 135 N.E.2d 231 (1956), discussed at note 133 supra.

259. See text accompanying notes 84-100 supra.

260. 9 Utah 2d 275, 342 P.2d 1094 (1959).

261. See Northwest Airlines, Inc. v. Glenn L. Martin Co., 224 F.2d 120 (6th Cir. 1955), ccrt. dcuicd, 350 U.S. 937 (1956) (applying Ohio law), discussed at text accompanying note 158 supra. 
ligence consists in violation of a statute or ordinance. ${ }^{262}$ It is only in the special situation where legislation is passed to protect a particular class of persons from their own inability to protect themselves from the risk created by violation of the statute that contributory negligence is not a defense. ${ }^{203}$

\section{ConCLusion}

It is evident that the rule laid down more than fifteen years ago in the Restatement of Torts, ${ }^{264}$ that a manufacturer's liability may extend to negligence of design, finally is coming to be of vital significance in the expanding field of products liability. The restrictive principles that the danger must be imminent or inherent, and that the defect of design must be latent, constantly are being narrowed in their application and replaced by the rule that the manufacturer is liable whenever he creates an unreasonable risk of harm.

As attorneys become increasingly aware of these developments, doubtless there will be a steadily increasing number of suits based on negligence of design or composition. While proof of negligence in this area is difficult, the more recent decisions show that where design negligence can in fact be established, the courts are overcoming their earlier reluctance to let design cases go to the jury. As a result, even where a defect in the production of an individual item may have been present, a plaintiff occasionally resorts to the theory of negligence of design to avoid the problem of showing that the defect, as distinguished from the improper design, existed at the time the product left the manufacturer's hands.

While manufacturers understandably are disturbed at this increase in suits, it is important that negligently injured persons be compensated. The manufacturers who decide to take more adequate steps to see to it that their products are of safe design and composition may find that their costs become appreciably lower than those of their less careful competitors. More significantly, manufacturers generally, instead of directing most all of their resources to making their products attractive and efficient, will give an increasing amount of attention to safety factors, with resulting diminution of loss to life and limb. Perhaps an occasional dangerous product, such as a highly inflammable dress or a chair of striking but unstable design, will be removed from the market, but most of the dangers, as demonstrated by the cases discussed, are ones that can be avoided by safety devices or alterations of design.

The foregoing analysis of the developing case law indicates that even in the more recent cases reliance has been placed on traditional negligence principles. There has been little tendency to invoke a rule of strict liability in cases based on allegedly dangerous composition or design. Outside of the area of food and drink, the few decisions imposing liability without fault have in the main been

262. Dart v. Pure Oil Co., 223 Minn. 526, 27 N.W.2d 555 (1947).

263. See 1 Frumer \& FrIEDMan $\& 13.01$ n.5.

264. 2 Restatenent, Torts $\$ 388$ (1934). 
restricted to things intimately used, such as drugs, hair dye, soap, or cigarettes. ${ }^{205}$ As a recent article points out, even most of the courts which accept strict liability as to food "refuse to apply it to such things as automobiles, tires, pumps, insecticides, anti-freeze compounds, electric blankets, insulating materials, lumber, furnaces, or a portable elevator."266

If in the near future the courts begin to apply strict liability principles to mechanical and other products where unsafe design is apt to occur, it then will be unnecessary to allege any acts of negligence, but it still may be necessary to determine, under some concepts of strict liability, whether a design is defective or dangerous. So, for example, it has been proposed that a section be added to the Restatement of Torts [Second], providing that a manufacturer of food be liable, even though he "has exercised all possible care," if the food when sold is "in a defective condition unreasonably dangerous to the consumer."207 If this principle should be extended to other products, where defective design or composition is alleged, when would the design be defective and unreasonably dangerous? To make the issue more concrete, suppose that twenty-five years ago not even those most learned in the field suspected that cigarettes might cause cancer. Could cigarettes produced at that time be regarded as of unreasonably dangerous composition, or as defective? Or suppose that a newly designed jet airplane, carefully planned by the best experts available, and given thorough tests, later develops unsuspected tensions which cause a wing to be torn off the plane when operated at its maximum speed. Probably this design would be regarded as defective and unreasonably dangerous, although it is not clear that passengers in such a plane, flying at a tremendous speed, should reasonably expect that it will be free even from flaws not yet discovered by any of the leading experts in the field. Perhaps liability even in this situation would be a useful means of spreading the loss; but that holding might unduly discourage the development of useful new products.

These considerations suggest that just as there is no bright line between negligence and no-negligence in the design field, there may be considerable uncertainty about what products are defectively designed under a strict liability rule. In the resolution of this issue, many of the considerations which have been discussed in connection with the negligence cases, such as the fore-

265. See Alexander v. Inland Steel Co., 263 F.2d 314, 318 n.6 (10th Cir. 1958), citing Noel, Mamufacturers of Products-The Drift Toward Strict Liability, 24 TENN. L. REv. 963, 989 (1957). See also Pritchard v. Liggett \& Myers Tobacco Co., 295 F.2d 292 (3d Cir. 1961) (applying Pennsylvania law).

266. Prosser, The Assault Upon the Citadel (Strict Liability to the Consumer), 69 Y ALE L.J. 1099, 1110-11 (1960). Several cases decided since the date of this article, however, have applied the strict liability principle to defective automobiles. See Henningsen v. Bloomfield Motors, Inc., 32 N.J. 358, 161 A.2d 69, Annot., 75 A.L.R.2d 1 (1960); State Farm Mut. Automobile Ins. Co. v. Anderson-Weber, Inc., 110 N.W.2d 449 (Ia. 1961). Cf. General Motors Corp. v. Dodson, 338 S.W.2d 655 (Tenn. App. 1960) (negligence and perhaps even concealment of defect present, but complaint alleged only breach of warranty).

267. See Restatement, Torts, Second $\$ 402 A$ (Tent. Draft No. 6, 1961). 
seeability of abnormal or careless use, probably will continue to be of significance. Certainly causation will continue to be a problem. With reference to contributory fault, while contributory negligence doubtless will disappear as a defense under a strict liability rule, still if the plaintiff actually is aware of the danger involved in a defectively designed product, and freely has consented to encounter this danger, such conduct doubtless will be a bar to his recovery. ${ }^{268}$

268. See Prosser, The Assault Upon the Citadel (Strict Liability to the Consumer), 69 Yale L.J. 1099, 1147-48 (1960). Cf. Keeton, Voluntary Assumption of Risk in Products Liability Cases, 22 LA. L. REv. 122, 166 (1961). 